\title{
195
}

y 1

\section{A PRACTICAL TREATISE}

ON

ENSILAGE SILOS.

ㅍ. W. IOSS \& 0 .,

FULTON, N. Y.

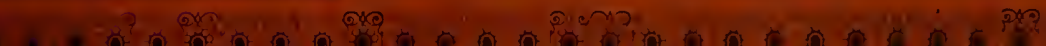
$1100000000000000010000 \mathrm{dT}$

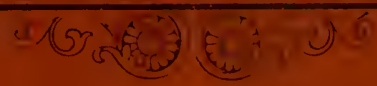



: 



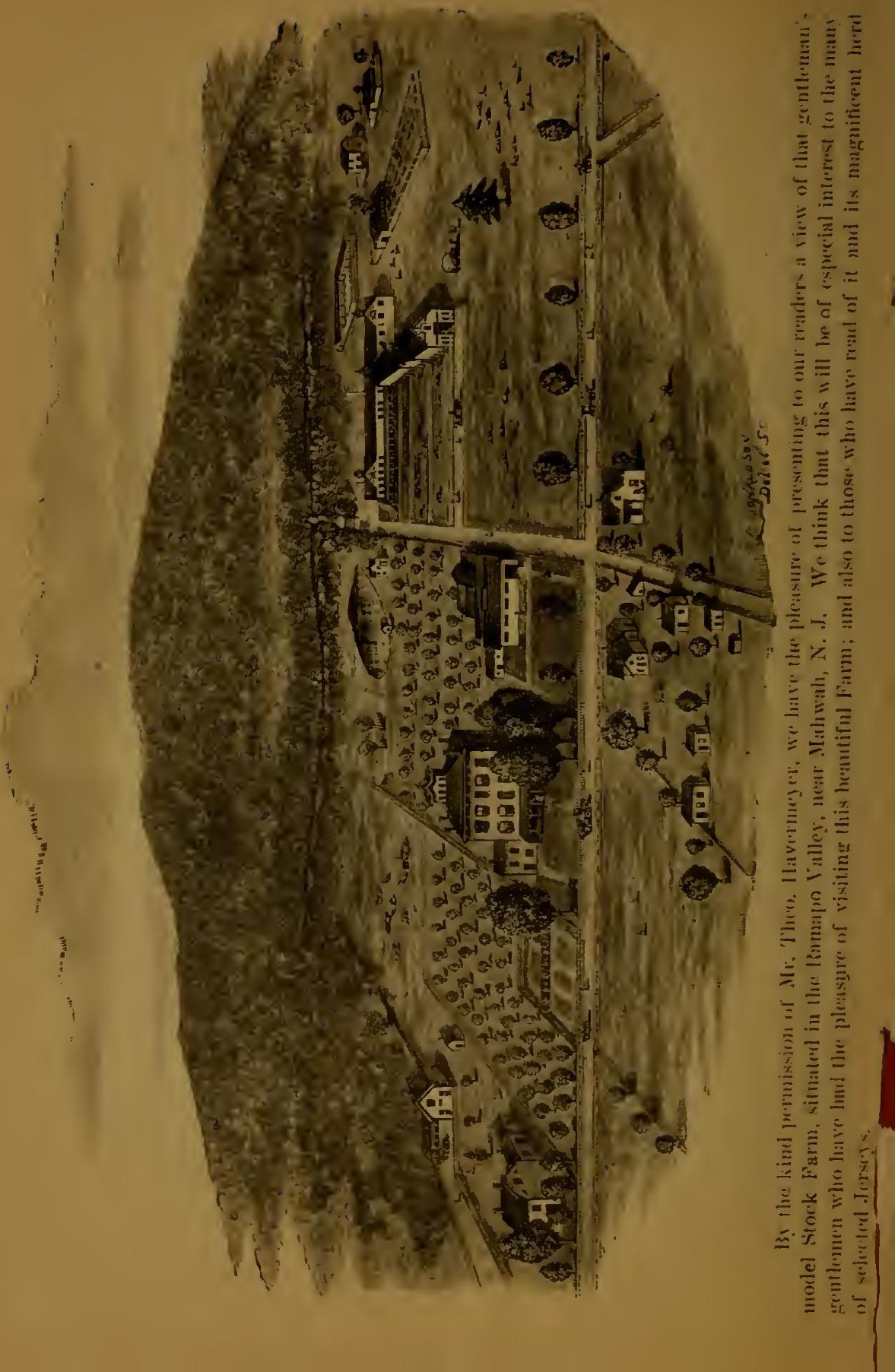




\section{A PRACTICAL TREATISE}

-

ENSILAGE AND SILOS.

CUNTAINLNG MANY VALUABLE LETTERS FRONL PROMII.

NENT STOCK-RAISERS AND FARMERS, GIVING THEIR

ACTUAL FXPERIENCE WITI EXSILAGE.

A BOOK THAT SHOULD BE READ BY EVERY FARMER IN THE LAND.

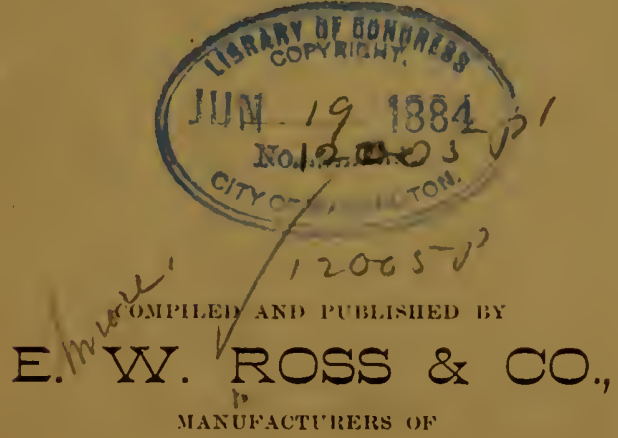

THE ROSS ENSILAGE AND FODDER CUTTERS, FULTON, OSWEGO CO., N. Y. 


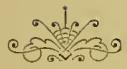

Entered, according to act of Congress, in the year $1 \mathrm{~s}_{4} 4$, by ELMORE W. Ross,

In the Office of the Librarian of Congress, at Washingt(m, I). C.

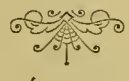

PRINTED BX

The Case, Lockitood \& Brainard Co., PRINTERS AND BINDERS,

HARTFORD, CONA. 


\section{PREFACE.}

It is not an uncommon occurrence for us to receive letters asking about ensilage, manner of building, cost of silo, putting in, etc. Althongh we have given the subject a great deal of careful study and attention, we are not sufficiently informed to always give the information desired. There has been a great number of books published on this subject, but most of them are from theory ouly, and do not furnish the hard facts that most farmers need. Believing that many farmers would adopt this valuable system of supplying green fodder for their stock in winter if they were informed on the merits and expense of it, we decided to gather all the valuable and practical information possible from our customers, whom we know that have given this system a thorongin and careful trial, and to publish it in book form for free distribution. With this end in view, we wrote to our ensilage friends giving in full detail our object, and requesting them to give us what information they could regarding the subject, what it cost per ton to raise it, get it in, store it, manner of building silo, whether above or below ground, cost of construction, and general ideas regarding it. They have responded to eur call very liberally, and we are thus enabled to give our friends who are interested in this subject some very important and valuable details on this great question. To our friends who have so kindly helped us in this work, we extend our heartiest thanks, and can assure them that they have thus extended a helping hand to their brother farmers, and we believe their kindness will be greatly appreciated. Without their kind aid we could not have obtained this valuable information, and to them we respectfully dedicate this book.

Yours truly,

April 2, 1884.
E. W. ROSS \& CO., Fulton, N. Y. 



\section{ENSILAGE.}

That ensilage is a success there can be no doubt. There is, of course, a large field for improvement, but, in the main, it is a success. It has been tried by some of the most cautious farmers in the land, who continue to use it, and who speak in glowing terms of it. There are very few farmers who would continue to use ensilage if it was not a profitable and satisfactory experiment. This, in itself, proves that it is all they claim for it. It is therefore fair to suppose that ensilage is a success. Otherwise it would soon come into disrepute. On the contrary, it has grown in favor very fast in the last two years. We can count a hundred silos now where we could not find one two years ago. Two years ago we endeavored to talk on this subject with a number of farmers, but they would not listen to the subject at all, did not believe that it was practicable, or a healthy food for cattle. These same people are now the most enthusiastic advocates of the system. There are, of course, a great many people who are opposed to this system of feeding, and will not listen to argument, or will not try the experiment. Of course, there are two sides to all questions. It is not to be expected that every farmer will adopt it, but we believe from our observations of it that, in a very few years, every farmer of any note will have his silo. As one of our friends says in his letter, it is simply canned goods, and is as proper food for cattle as canned fruits are for people. It is but a few years since that canned fruits have been generally used, and people could not now do without them. We know, of course, there are some agricultural papers who do not advocate this system of feeding, hut a great many of the agricultural papers do approve of it, and are 
very loud in their praise of it. It certainly has been a very great benefit to a number of the farmers throughout the country, especially to those in the New England States. A great many of the old farms there had run down, and could not feed over five or six head of cattle, that now by using ensilage support from thirty to forty head. We believe that the ensilage system is a boon to mankind generally, and we have taken great interest in it, not because we make a specialty of ensilage cutters, but because we believe it will benefit the farmers, and also the animal creation. There are hundreds of cows that live on straw and poor hay all winter, and come out in the spring hardly able to stand, simply because the farm does not produce enough to feed them. It takes about one-half of the summer for these poor animals to get recruited and in condition to give a reasonable quantity of milk, and some never recover from it. With the ensilage system these cows would give milk all winter, and would come out in the spring in splendid health and condition, and the expense would be no more. This would be, of course, very profitable for the farmer, to say nothing about the comfort and enjoyment of the animals. We know that most farmers let their cows go dry from three to four months in the winter season, because they have not enough to feed them on, or because they have not ambition enough to do the work of milking, etc. To the latter class we have nothing to say, but to the progressive, enterprising farmer we hope our book will be a benefit. Our experience has not been great in the dairy business, but enough to satisfy and warrant us in making the above remarks. A trip through our own county in April, when the cows are first turned out, will verify our statement. We have given this our attention, and notice that our county is not alone in this. The main difficulty lies in farmers not having the ambition to try new experiments. Of course, somebody has to go on and make experiments and improvements in all spheres of life and trade. Otherwise, we would be no further advanced than we were a hundred years ago. There is 
just as much chance for improvement in agricultural pursuits as there is in any other branch of business. There is not a month but what there is some new machinery or new ideas developed for cheapening and improving manufactured articles. There is no reason that agiiculture shonld not progress as fast. There has been a great advancement in agricultural instruments to facilitate getting in different products, grains, etc., but heretofore there has been nothing done to increase the supply of milk, and to prepare a feed to produce the same results in winter that grass in the summer season does. It is very difficult through the winter and spring months to obtain nice yellow butter, and it always commands a very high price, and especially if it is made without coloring. We are told that ensilage makes excellent butter, and gires it the color of fall made.

IVe have had many letters from customers whom we have sold our feed-cutters to regaraing the question of ensilage, and it is a pleasure to read their experience. Many of them have had heavy mortgages on their farms for years, and were utterly discouraged; as a last resort, built small silos, and increased their stock; and we have letters now in our possession saying that, by the aid of ensilage, they have lifted their mortgage, increased their stock, and are in better circumstances than they have ever been before. Such news is always pleasant to hear, whether it is from the cause of ensilage, or anything else.

Too many farmers have the impression that it is necessary to be rich, or what they call fancy farmers, to adopt this system. This is erroneous. Any farmer that has from four to ten cows can afford to build a silo, even if he has to run in debt for it. It is very simple and inexpensive to build a silo large enongh to experiment. It is not any more expensive to cut it green than it is dry, and fodder should certainly be cut, and in this way each farmer knows from his own experience whether it is a profitable thing for him. Of course we understand that what is profitable for some farmers is not for others. We have talked with a great 
many farmers about putting in silos, and they have remarked that it was well enough for rich people, etc., but would not do for them. There has been a great many valuable articles written on this subject, and if our farmers read them would perhaps be benefited thereby, but we know of a great many farmers who never read a paper, and consequently do not keep informed. We hope that this book will reach all such people, and that they will find some valuable and useful information in it. A silo built of wood and above ground, or partly above ground, would be useful for other purposes, in case ensilage proved a failure. There is always use for such buildings, such as ice-houses, etc. We are glad to see progress whether it is in agriculture $\mathrm{Or}^{\circ}$ manufacture. It is a well-known fact that farming is the foundation of all business and prosperity. When the farmer prospers; we all prosper. It is therefore for everybody's interest that the farmer should succeed. Money spent in agricultural implements goes to the manufacturer, thence to his employees, and continues on its endless journey. To say that we are not directly interested would not be true, for we are, and so is every manufacturer in the land. Every business can trace its main resource to agriculture, for it is the one important industry of the land.

We do not publish this book as a production from our own pen, and will not therefore attempt to champion the cause of ensilage. The letters we publish herein are from reliable and progressive farmers, giving their experience, which we can vouch for. These letters speak for themselves, and anything we can say will not in any way add to the valuable knowledge these letters give. Farmers who wish to advance with the age, and improvements of the times, must turn out of the old rut, and adopt the new system. There are too many mistakes made by doing as our forefathers did. The one great idea of business is to turn out double or treble the same amount of work at the same expense of former years: There is no reason why farmers should not do the same. Of course there is a greater quantity of diary products used than there was a few 
years ago. The population of the United States is steadily increasing, and this lemand has got to be supplied. The farmer that adopts the best systems of producing a good article at the least money is the one that will succeed. We know that a great many of our farıner friends think that unless an article is high, it cannot be raised profitably. If they will examine the prices of all kinds of machinery, and compare them to-day with the prices of the same articles five years ago, they will be very much surprised at the difference. Yet our manufacturers make as large a per cent. as formerly, but they are obliged to do a much greater business to make the same profit, but this is as it should be, for it employs a great many more people, and makes greater activity in business life. We can remember when the mowing machine and reaper were first invented, the laboring people were very much alarmed for fear they would be out of work; that these machines wonld take their place, but the men that used to use the scythe are now at work in factories helping build machines.

We sincerely hope that this little work of ours will be of benefit to some of our farmer friends, and that we shall have the satisfaction of knowing that we have assisted some of them in making their farms more profitable. Whether they use one of our cutters or somebody's else, we would like to see them adopt this system of ensilage, for we believe it is a great thing, and we are strong advocates of it. We have, since we commenced this book, received some very encouraging letters from farmers, saying that they think it a very commendable work, and believe it would be more valuable to farmers than anything ever printed on the subject. It was what the farmers in general required, and they were very glad indeed to hear that we have undertaken the task. These letters have encouraged us to go on with the work.

E. W. ROSS \& CO. 


\section{EXPERIENCE WITH SILOS AND ENSILAGE AT LAKE- SIDE STOCK FARM.}

\section{Syracuse, N. Y., February.}

BUILDING A SILO.

Where nature has so bountifully supplied man with the necessary material with which to build concrete walls, as in Onondaga County, there is little occasion for human ingenuity to be exercised in any other direction. Therefore it was decided, late in the summer of 1882 , to build a silo with heavy walls of concrete, using slag from the blast furnace, instead of stone or gravel, which cannot be found at Lakeside. The location chosen was alongside the main hay and cow barn where we could get a length of forty feet, a width of eighteen feet, and a depth of nine feet; thus utilizing a heavy and substantial wall on which the barn rested, for one side of our silo. Through this wall a door was cut giving suitable and convenient access from the cattle-stable in the basement. The ontside walls were laid out two feet in thickness, with a division wall sixteen inches thick, and at right-angles to the barn or basement wall, thereby giving us practically two silos, either of which could be opened without disturbing the other. For uprights or guides to the wall while building, we used hemlock $2 \times 4 \times 16$, about five feet apart, outside and inside the proposed wall, set and fastened firmly in a plumb position, two and one fourth feet apart as measured across the proposed wall, allowing the $\frac{1}{4}$ foot for the inside or guide-planks, which planks were sixteen inches wide, placed and fastened close to the upright guides, thus leaving between them exactly two feet for the wall. The guide planks being in position for both outside and division walls, and a little mortar firmly pressed 
along the inner and under side of them to prevent the thin cement from running away, prepared the work for the first course of sixteen inches. The slag varying in size from a pebble to a good sized cobble stone was shoveled into this huge trough as it were, no special care being exercised to place them except at the corners where building stone were occasionally used crosswise to add to the strength. After filling level with the guide planks, cement was prepared in a barrel with a crank attachment and internal gear to thoroughly stir and mix the ingredients placed therein.

The best water lime and sand were used in the proportion of three of the former to ten of the latter, placed in the barrel through an opening in its side. Water sufficient to give the mass the consistency of thin cream was used, and therefore the same amount of the ingredients were placed in the barrel to insure an even strength and consistency. A few revolutions of the crank and the perfectly mixed cement was drawn from the barrel, through a faucet at the bottom, and conveyed to the slag in a trough. The operation was, of course, repeated until all the interstices were filled even with the top of the guide-planks. One day was allowed for the mass to set and dry, the time being gradually reduced as we approached the top, when only five hours were required. By spreading the upright guides a little, the planks were easily raised without injury to the wall, when the same operations were repeated until the required height of sixteen feet was reached, the bottom was cemented and a board roof put on which completed the silo; the dimensions being, length, thirty-five feet, breadth, fourteen feet, and depth, fifteen feet.

This silo was built with the aid of farm laborers only. The sand and lime were drawn fully four miles, and the slag one and a half miles. A careful account made at the time, of each and every expense, including an item of $\$ 50.00$ for excavating and banking, showed the total expense to be $\$ 350.00$ for a double silo finished, ready for filling, with a capacity of 165 tons at the lowest calculation of forty-five pounds per cubic foot. 
This double silo was filled with corn, cut $\frac{3}{4}$ of an inch long with a Ross power cutter, covered tightly, with plank, the cracks battened, and all weighted with eighteen inches of stone over the entire surface. In early winter when opened, the corn came out fresh and bright, with a sweet smell, and slightly acid taste. All visitors examined the silo and ensilage, and many remarked: "Oh! You are feeding sour.krout too, are you?" The Farmers' Club discussed ensilage, and the wise opposers ridiculed the sour-krout and alcoholic feed, not even sparing the good Deacon who had built a fine silo and found his corn ensilage a good feed for the production of both milk and butter.

Perhaps they feared the coming generation might acquire a taste for strong drink from the milk of cows fed ensilage. We fed our ensilage, however, not yet having developed that moral perfection strong enough to deter us from feeding it, for fear of the volatile alcohol, and the imaginary fear of evil consequences. Is it not a preferable feed to beer grains, refuse from glucose factories, musty hay, old cabbage or turnips? Is not the aroma of ensilage fully as pleasing? I have yet to hear of the first complaint of poor quality in either milk or butter from cows fed wholly or in part on corn ensilage, and the consumers of Holstein butter manufactured at Lakeside are among the best families of Syracuse, and unexcelled in epicurean taste.

For the best quality of ensilage I prefer a strong-growing sugar corn sowred thin enough to allow each stock to develop a fair sized ear. Such corn should be cut when the ears are in the milk. or roasting stage, immediately run through an ensilage cutter and packed in the silo. I am strongly of the opinion that a silo should be filled and weighted heavily the same day, to avoid the heating and souring that so soon takes place if the silo is left open. Sugar corn ensiloed in this manner in a nearly air tight silo can be relied upon to produce a deep rich flow of milk little inferior if any to the finest June pasture.

The expense per ton of raising and ensiloing a crop of corn is 
variously estimated by those experienced in the matter. From past experience I judge that a crop of corn yielding eighteen tons per acre can be raised on our muck land for an outlay of $\$ 9.00$ per acre for labor, seed, and fertilizer. My figures are as follows:

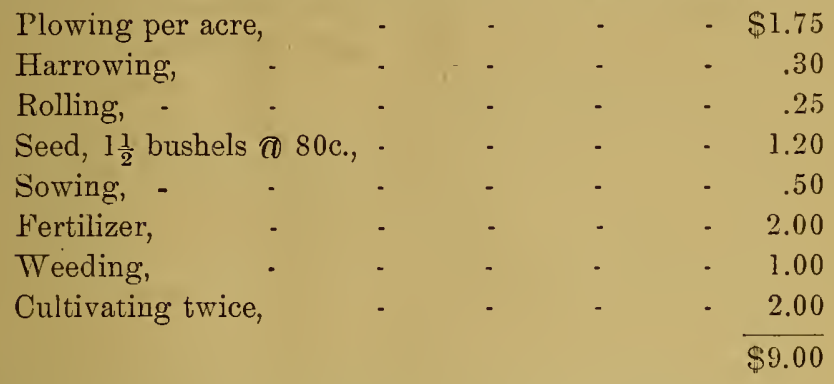

Should the crop exceed eighteen tons per acre the cost per ton is reduced as the expense of raising the heavy crop is no more per acre.

Last season under unfavorable circumstances, using an ensilage cutter too small for our force of men and teams, drawing our corn fully three-quarters of a mile, we ensiloed forty tons per day of eleven hours, at an expense of $\$ 35.00$ or $87 \frac{1}{2}$ c. per ton. Lessen the drawing distance one-quarter mile and the expense is reduced one team at least. Our cutting expense in the field is light, as boys are employed and placed in charge of a competent man who directs them, and the corn is cheaply cut, placed in bundles as large as a man can easily handle, ready for the wagon and loaders.

I think we can safely calculate on eighteen tons per acre, and am sure some acres of our last season's crop exceeded it. I have arrived at the above estimate by actual weight of an accurately measured fraction of an acre. It is very large corn that will weigh twenty-five tons per acre.

Only a very limited and incomplete experiment has been made at Lakeside to test the milk or flesh-producing qualities of ordinary corn ensilage, grown too thick to admit of forming ears, cut and 
ensiloed after a slight damage was done by frost. Three pairs of two years old heifers that had been milked from ten to eleven months were carefully weighed, and fed as follows for a period of thirty days. The amount of milk produced by each pair in ten days preceding the test was compared with the amount produced the first ten days of the test. The result appears as follows:

Pair No. 1. Fed ensilage alone.

$$
\begin{aligned}
& \text { " " } 2 \text { " " " and } 3 \text { pts. cotton seed meal daily to each. } \\
& \text { " "3. " " and former feed of } 4 \text { qts. bran and } 4 \\
& \text { ground oats mixed, to each daily. }
\end{aligned}
$$

Pair No. 1. Gained in weight $8 \mathrm{lbs}$.

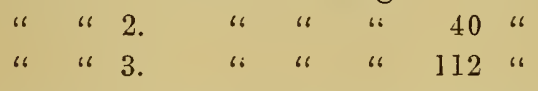

Pair No. 1. Fell off in milk an aggregate in ten days, 41 lbs, 15

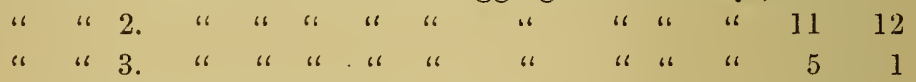

It should be borne in mind that these were imported Holstein heifers with their first calves, recently released from quarantine, in poor condition, having calved in mid winter, milked nearly a year and all but one due to calve again in three months, every circumstance unfavorable to a continuance in milk; therefore I think it remarkable that the shrinkage in milk for the time was no greater, not even so great with pairs No. 2 and 3 as the natural shrinkage. It is a virtue of Holsteins to continue in milk a long time, and a virtue of ensilage to help them do it.

The comparative value of corn ensilage depends greatly on its quality; that which is all stalk and leaf being inferior to that which contains the natural grown ear in the milk stage of growth. Comparisons are generally based on ensilage made from thicklygrown corn devoid of ears, which by many is estimated; three tons of ensilage equivalent to one ton of hay. I assume this to be correct. An acre of fertile land should produce two tons of hay. An acre of our muck land will produce eighteen tons of corn 
ensilage. An ordinary cow will consume three tons of hay in the six months feeding season of our northern winters, or an average of $33 \frac{1}{3} \mathrm{lbs}$. per day. By the ratio of one to three we find $33 \frac{1}{3} \mathrm{lbs}$. of hay equivalent to $100 \mathrm{lbs}$. of ensilage. One acre of hay would therefore feed ten cows twelve days, while the acre of corn would feed the same number thirty-six days. Valuing the land at $\$ 100.00$ per acre and allowing $\$ 5.50$ for interest and taxes, the expense of producing the eighteen tons of ensilage and ensiloing the same would be increased from $\$ 1.37 \frac{1}{2}$ to $\$ 1.68$ per ton. The daily feed of $100 \mathrm{lbs}$. would therefore cost .084. The acre of hay of two tons can be cut, raked, drawn the same distance we drew our corn and put in the mow for $\$ 2.25$. Adding interest and taxes for this acre as before, we have an expense of $\$ 7.75$ per acre or $\$ 3.87 \frac{1}{2}$ per ton in the mow, and $.0645 \mathrm{c}$. for the daily allowance of hay, $33 \frac{1}{3}$ lbs., a difference in favor of hay of nearly.02c. a day per cow. The best is the cheapest. Corresponding to grass of summer is the corn ensilage of winter, rich, succulent, easily digested, and quickly assimilated, producing a deep, rich flow of fine-flavored milk, yielding butter of the finest quality.

In order to properly winter the immense stock of Holsteins at Lakeside, we must purchase hay and grain, or make and fill more silos. Hay delivered, costs at present $\$ 9.00$ per ton. Comparing the cost of a daily feed of $33 \frac{1}{3}$ l'os. of this hay, when purchased, with the daily feed of $100 \mathrm{lbs}$. of corn ensilage grown and ensiloed on the farm, we find the daily allowance of hay cost us fifteen cents, or nearly double the cost of the daily allowance of ensilage. Now shall we continue to buy hay, which may advance in value, or build more silos? To build more and fill them well, seems a practical solution of the problem.

By the use of a few figures we have learned, that, as a matter of economy, we must produce a large crop of corn of good quality, and while we may not equal the estimates of enthusiasts, we should be satisfied with nothing less than twenty-five tons per acre, which will reduce the cost of the daily allowance of $83 \frac{1}{3}$ lbs. to .0727 . 
The interest, taxes, and growing expenses being divided among the greater number of tons grown, lessening those expenses per ton.

Our experience with clover ensiloed has not been as favorable as with corn, owing partly to lack of experience, but more to the following causes. The season of 1883 caused a quick heavy succulent growth of very. coarse clover, consequently it lodged badly and partly decayed at the bottom. The frequent showers at the time of fill. ing the silo. wet the clover, causing it to remain in that condition a long time, and prevented our getting a large proportion of it in other than poor condition. Filling the silo under these unfavorable circumstances caused the mass to turn black, and gave it a strong disagreeable odor. Cattle eat it greedily however, often leaving corn ensilage to eat it.

Mr. C. M. Armstrong, manager of the Remington farm, Cazenovia, N. Y., now operated by Smiths \& Powell, details the same experience with a little of his clover which received a light shower while that which he ensiloed free from water came out fresh, bright, and green.

How to produce ensilage of a uniformly good quality, is one great question to solve. Perhaps the theory of Prof. Miles of Amherst Agricultural College, Mass., will throw light on the mystery why some ensilage is very sweet, and other ensilage very sour.* We need light on this important point, and in an age of progress like the present, have every reason to expect it.

At present we are feeding forty milch cows an average of 55 lbs. of corn and clover ensilage daily, in connection with hay and grain, producing a large flow of milk, while the cattle are easily kept in the finest condition, and as we do not feed one-half the hay we otherwise would, it is evident we are feeding our stock better, and cheaper than on hay and grain both purchased.

In conclusion, I will state that so far as my experience extends, I find no objection to good ensilage, but strongly approve of it in

\footnotetext{
* Co. Gent., Vol. 49, page 104.
} 
our system of feeding. My figures are from notes made at the time, and on the ground, and may appear too small to those less favorably located. I trust they may provoke a friendly spirit of criticism and discussion which will tend to eradicate errors of thought so fatal to true progress.

JNO. T. CLAPP, Superintendent.

Messrs. E. W. Ross \& Co.

Exfield, N. C., February 15, 1884.

Gentlemen :- In compliance with your request of $12 \mathrm{th}$ inst., asking my experience with silos and ensilage, I cheerfully give you my experience, extending now over nearly four years, having built my first two silos in 1880 .

These were built of cement and stone, eight feet deep, twelve feet wide, and fifteen feet long, which cost me about $\$ 300.00$.

These I filled in the latter part of the summer of that year with pea vines two-thirds, and the remaining third with green corn and pearl millet.

I opened one of the silos about a month after filling, and found the ensilage in good conditon. I at once commenced feeding it to my horses and mules, as well as cattle. All soon became very fond of it, and the horses and mules stood their work as well, and kept in as good condition as when fed on the best of fodder and hay. Since this time three-fourths of all the long forage they have eaten has been ensilage, and another year's experience strengthens my former convictions as to its safe and economic results.

In 1881, I built two more silos above ground, or rather excavated two feet below the surface, thiniking at this depth I would be safe from water (in this I was mistaken, as water rose in the bottom in very wet seasons, three or four inches deep).

These last were built of wood, by making double walls of wood 
twelve inches apart, and filling in with earth, thus making them air tight, which is all that is required. These were twenty feet long, ten feet deep, and twelve feet wide, costing me not to exceed $\$ 100.00$, and holding at fifty lbs. to the cubic foot, sixty tons each, or 120 tons; this I estimate cost me not over eighty cents per ton.

Last summer some of the inside wall of boards had decayed, requiring their removal.

I tried to avoid the use of earth between the walls, thinking I could make an air.tight wall without it. I first made a wall of twelve inch plank (one inch thick), then after applying a coating of coal tar, I put on another course of the same plank (breaking the joints), after having applied the tar to these also, and nailed the tarred sides together firmly to the studs. About one month after first filling them, I took off the weights to refill them, and found the ensilage next to the wall hot and commencing to decay. I immediately nailed boards to the outside of the studs and filled the space with earth as at first, which at once arrested the heat and decay. I found when the silo was opened for feeding, that at some parts of it the ensilage next to the wall for some two to six inches was dark colored and decayed, and of course was unfit for use. The balance was in good condition. The wooden silos above ground with the aforesaid exception, has kept the ensilage in as good condition as those built of cement below the ground. This fact I think should do away with the idea of expensive silos. I effectually got rid of the water rising in the bottom of the silos by digging a well just outside of them at one end four feet deeper than the silos, then digging a ditch twelve inches deep and six inches wide in the middle of them, running their entire length, and filling same with small stones, with a hollow tube from the end of the ditch emptying into the well, which requires to be pumped out as often as the water rises to the level of the silo, or in any case about once a week. As I have no cause to change a statement of items of cost of ensilage made to the Ensilage Congress in 1883, I reproduce it. 
Manure for 15 acres of pea vines, $500 \mathrm{lbs}$. per acre, made of chemicals, cotton seed, and stable manure, costing $\$ 16.00, \quad \$ 60.00$

Preparing and planting same, $\$ 2.00$ per acre, - $\quad$ - 30.00 Cultivating and plowing, $\$ 2.00$ per acre, - - - 30.00 Hoeing, \$1.00 per acre, - $\quad$ - $\quad$ - $\quad$ - $\quad$ - 15.00

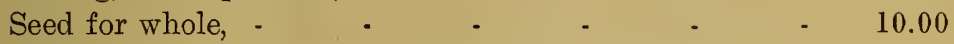
Labor for delivery at silu, cutting and weighting 3 silos, $\quad 80.00$ $\$ 2 \longdiv { 2 5 . 0 0 }$

Wear and tear of machinery, interest, etc.,

Deduct seed saved from vines before ensilaged, Net cost of 125 tons ensilage, $\quad \frac{50.00}{\$ 275.00}$
$-\quad \frac{100.00}{175.00}$
$-\quad \$ 1.40$ Cost per ton,

This is for cost of ensilage made from pea vines which I have always believed superior to that made from corn. I now have the annual report of Prof. Dobney, of the North Carolina Experimental Station confirming this opinion.

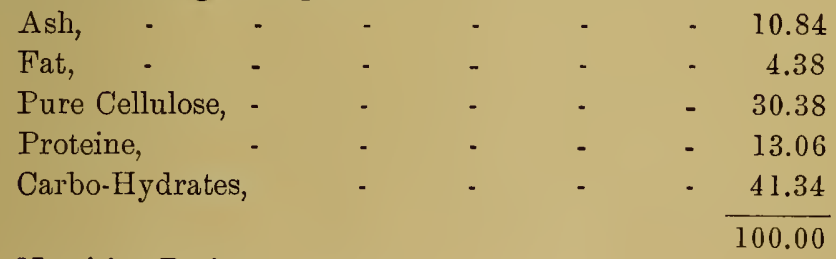

Nutritive Ratio, 1: 5: 82 .

For the purpose of comparison we produce an analysis of corn ensilage by the same party, as follows:
Ash
Fat,
Pure Cellulose,
Proteine,
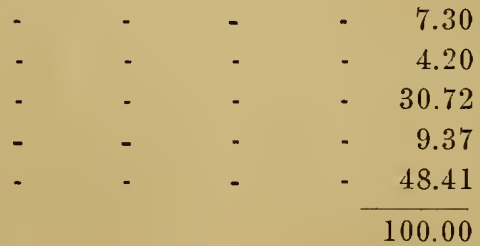

Nutritive Ratio, 1: 8: 89. 
Thus it will be seen that the relative value of pea-vine ensilage far exceeds that made from corn. I am thus particular in drawing attention to the advantages of the cow pea for ensilage, besides its superiority as a food, it is by far the least costly of any ensilage plart we can cultivate. It matures a full crop in eighty or at farthest ninety days, and is less affected by extremes of the season, either wet or dry, than any other crop. I think, from my experience, it is superior to any plant known for this purpose.

As many tons can be made to the acre of them as corn under the same conditions. Of course there is great difference in their habits, some making but a comparatively small growth of vine, while others make a very rank growth. The latter only should be grown for ensilage, as a matter of course.

To sum up I think ensilage made of pea vines superior to any food I have ever fed to horses, mules, and cattle (have never tried it to hogs and sheep).

That through the silo is the most economical way that food can be transferred, from the field to the stall; that unlike by desiccation there is absolutely no risk from the green plant to its security in the silo, and almost perfect food, and that it is only a matter of time when the system will become universal.

I do not consider the system has been perfected, as no doubt many improvements will be made from time to time.

I find the most economical, as well as the easiest method of weighting silos, is with common earth, put on about two feet deep. Yours respectfully,

C. W. GARRETT.

Charlton, Worcester Co., Mass., March 10, 1884.

Two years ago I was aware that my hay crop would be short. I had read a good deal on the method of preserving green fodder. 
The idea struck me that I could build a cheap silo in an old barn bay which stood off away from the main buildings and would not be wanted for any other purpose. I commenced planting corn about the first of $\delta$ une for fodder on some fields that were in grass but looked as if there would be a very light crop. I spread barn yard manure on the grass ground and turned it under, and planted on the sod with Russell \& Co's. superphosphate of lime, New Jersey, in the hill, $300 \mathrm{lbs}$. to the acre. Hills about fifteen inches apart, planted with machine. The evergreen sweet corn about three and a half acres. Hoed once by hand.

It made a large growth the fore part of the season; came on dry and cut it short one:half what it would have been, had it been a common season. However, I had a good lot of fodder and it eared out well. I comnienced for a silo in the bay of the barn. Boarded inside the frame with rough boards twelve feet high, nine feet by eighteen inside on floor. Packed between boarding with sawdust, and papered inside with builders' paper, thinking to make air-tight, filling the bottom with dirt up to top of sill, and laid a floor. This completed my silo work, all done with farm help; cost inside of $\$ 20$.

This was arranged for this present crop, thinking if satisfied with the system, I would build something permanent.

I commenced filling September 10th; some days were dry and some were wet. Hired a Bailey cutter, small size, run it with one horse tread power, cut three-quarters inch long.

The ears on foader broke the cutter bad, but I managed to run it through by breaking off the larger ears in time; made rather an expensive job for me.

It took most of the time for one week to put in and weight it500 lbs. to square yard-six men, two teams. When settled to its lowest point, there was 1,300 cubic feet. I thought my field of corn, with all my expenses, in rather a small compass. Being told by some ensilage men that I would be satisfied when I come to feed it out, I was contented. 
Opened the silo January 1, 1883, fed to twenty-two cows nine weeks, one busbel per day each, or about 30 lbs., part in milk, part dry, all coming in in the spring. Their keeping besides ensilage was hay, first quality, with straw once per day, with meal to those that gave milk as before, oxly. They gained on milk one-fourth, less than one week's time. The dry cows gained in flesh. I also fed to fourteen yearlings about $15 \mathrm{lbs}$. per day with poor hay and straw for nine weeks.

They gained every day from the commencement. It seemed to be something they wanted. When we were about to feed it they were always ready to come into the barn as quick as the door was open. It is a good substitute for roots and is very much cheaper to raise.

The ensilage did not keep well in this silo. There were rotten corners, and all around the outside, six inches or more, where the air got in. I think it would be a nice job to build a silo of wood, that would keep it perfect; it is necessary to have it tight enough to hold water, then if properly filled in will keep without any loss.

With my experience I should say that a silo made of wood would he most expensive in the end. The ensilage would rot it in a vèry few years, so as not to be of any use.

Being satisfied that ensilage was good feed, and feeling confident that I could build a silo that would be for my interest in farming, I commenced one to open into my main barn for feeding, 24 feet $\times 12$ feet, 16 feet walls inside, built of cement and stone, with $20^{\prime \prime}$ walls. Setting studding inside and out with plank 12 " wide with even thickness for the curb. Put one part cement to five coarse sand with all the stone I could bed in, being careful not to have them near the plank to prevent raising. Raised the plank as fast as it set so as not to break up; completed the walls, put on the roof, all with common laborers at $\$ 1.50$ per day-board them. selves Plastering inside and out with one part cement and two parts sand, which required a mason at $\$ 2.50$ per day, which cost me about $\$ 400.00$. This including digging out and draining for 
foundation, 50 loads sand, $\$ 60.00$. Lumber, $\$ 33.00,80$ bbls. cement at $\$ 1.50$ per bbl., $\$ 120.00$.

This was built on a foundation eight feet below barn-floor; about one-half in ground, with door level with floor for taking out ensilage. The door for filling on the opposite end, on top of walls, five feet from ground. I had four acres of corn planted for fodder in drills $3 \frac{1}{2}$ feet apart, partly Maryland white and part sweet, fertilized same as last year. The season was very dry, and it dried up badly; being so thick it dried worse than if planted in bills, and I got no ears as I did last year. I commenced filling in the silo 15th September, completed the job of fodder corn, and found room for more. Had six acres planted for corn. I had the ears picked, dropped on the ground, cut the fodder also; it being very dry, I wet it down so as to have it tramped down solid. Kept a horse on silo while cutting-cutting with the Ross Cutter, Little Giant, No. 14, three-quarters inch long, run with one horse tread power, with elevator twelve feet long, which carried it into the middle of silo, weighted as before. I found this to be decidedly the cheapest way to harvest. The corn was dry enough so as to keep without any trouble. When the ensilage in the silo was settled to its lowest it was twelve feet deep. This will keep thirty cows, one-half their hay keeping $4 \frac{1}{2}$ months, - equal to two months and seven days whole keeping and in better shape than it could be done on hay without any grain. I think they will do better on both, than either one alone. There is not one bushel in the whole amount wasted. It is just as good on sides and corner as any part of it. This silo will hold water up to the door; that is what is wanted in order to have a good ensilage. I am going to plant this season some late variety of corn that grows large fodder to plant in hills fifteen inches apart one way, and $3 \frac{1}{2}$ feet the other; cultivate and hoe so as to get some ears of corn, and cut when in the milk. I shall be ready this coming season; my silo is built and will not rot out in my lifetime. I have not met a man 
that has tried ensilage but who speaks favorably of it and intends to increase his amount.

The cost of raising corn for ensilage depends very much upon the land, whether in high state of cultivation or poor; light land works much easier, and can be done principally with horse power. Heavy land, clay, would have to be worked by hand principally. I think one acre of corn for ensilage could be raised and put in silo from eighteen to twenty tons, "which would be a good average," after the fertilizer was on the ground, for $\$ 25.00$; my advant. age is my land is mostly clay soil. I believe that every farmer will eventually adopt this way of providing for his cattle in win. ter, my silo being one of the first in town. I have had a great many callers from those who intend this coming summer to build silos.

LEVL L. HAMMOND.

Scotland, Conn.

I have a farm of fifty acres. I have worked it fifteen years. I could keep but three cows and two horses, and could not improve it to keep only that number. It is now February 7,1884 . Two years ago I built a silo of 1,000 cubic feet. It cost me to cut the ensilage and pack it into the silo, "ten dollars." I kept through the winter on ensilage and hay, from my farm, five head of cattle and two horses. I found my cattle in the spring in better condi. tion than usual, and my farm improving.

I enlarged my silo by building on the top 700 cubic feet this present season, and am keeping eight head of cattle and two horses, and shall have more hay than I shall need to keep my stock. It cost me to cut and fill my silo this season, $\$ 16.00$. I shall sow more corn next season, and if I cannot get it into my silo, I shall cut it and feed dry. 
I cut my ensilage with a Daniels cutter. T'his season I shall have a Ross cutter of greater capacity, which makes it cost less to cut.

JONATHAN ANTHONY.

Messrs. E. W. Ross \& Co.,

Raletgh, N. C., March 5, 1884.

Sirs:-Mr. Mohler handed me your letter and requested me to answer it. Mr. M. and I are the owners of Thomasburg Vineyard. I tried ensilage as an experiment, and in answering your letter I will state facts which may not occur in other letters. I built three silos under one roof, each ten by twenty feet. The first had a cement floor with dressed wooden sides of two inch plank. This silo was filled with corn alone, August 1, 1882, and when compressed was about six feet deep. It leaked very freely from juices, and I thought it had spoiled. About February 1, 1883, I opened the end as directed in the books and found it sound. I exhibited it to different parties, tried it with horses and cows, and they seemed to like it. It stayed open until about June. I then commenced to use it regularly, hauled it three miles to town, twice a week, in bags, and are still hauling it at this time, as my stable is small. It is as bright color and sound to-day as it ever was. My cows give more milk, from it, my butter is yellow, and turns partially when the cattle do not have the ensilage. The horses only get one bale a day, because it sweats them, but, they prefer it to any other forage. A half broken mustang will not eat it until it gets warm. The other two silos were lined with brick and cement on account of the first leaking, but I would not line them again. They have about eight feet of compressed corn, field peas, and vines, from the bloom to the mature pod, which I regard as the 
best material out of which to make ensilage in the Southern country. I expect to find them entirely sound when I open them.

I hope this fall, in Eastern North Carolina, to try some silos composed of corn, field peas, crab grass, and partially dried peanut vines. In this $I$ expect to get a richer ensilage than any yet made.

I used your cutter, No. 11, I think, first with steam, and then with horses. It required four horses with sweeps to give it sufficient speed. If I had sufficient power I would much prefer No. 18.

I think there were only two things requisite to succeed with ensilage: cut the material one inch in length or less, and let the weight on top be heavy and fall as long as ensilage will give.

$$
\text { I am respectfully, THOMAS D. HOGG. }
$$

N. B.-The wood of the silo decays rapidly when it comes in contact with the ensilage, and yellow pitch pine gives a slight taste to the ensilage for about an inch.

E. W. Ross \& Co.

Barrington, R. I.

P. O. Address, S. Seakonk, Mass.

Dear Sirs:-As you wish to know what results have come from my efforts to test silos and ensilage, I will give you a description of the past year's experience.

Farmers cannot afford to experiment too often, for a failure means a loss of time (and time is money), besides the actual outlay of cash.

While expensive silos were advocated I hesitated, for the amount of stock on my farm was not large enough to demand such costly storage, but the increase of my wife's pet Jerseys called for more 
food than I could raise in the form of hay without too much expense, as my soil is high and sandy. Now I work a farm for profit, (and therefore for pleasure,) and as this farm of twenty-five acres was run down and had never fed more than two cows and one horse, yet my success in building up others that were in the same condition gave me faith to try this one, and I now keep one horse, a yoke of oxen, four cows, and two yearlings, by the help of a cheaply built silo. My ensilage is now (March 1st;) nearly all fed out, and have hay enough to last until my seven acres of rye will be ready to cut for fodder, when some corn will follow in time for the silo in the fall. We need not fear the frost as in the past when silos were not used.

Prove all things and hold fast to good. The silo has come to stay. There is no need of useless expense. My wealthy friend has four silos built of heavy masonry, and says he shall build four more, and yet his ensilage is preserved no better than that which I fed from a cheaply built board silo.

My barn is arranged so that the floor for cattle is four feet below the level of the ground. The walls are stoned up to the level with brick work above the ground three feet high; this gives a good temperature both winter and summer, and good ventilation; above is a common board barn for storing hay, etc.

I partitioned off a space $8 \times 16$ feet at one end of my barn, using $2 \times 4$ joists, with $1 \frac{1}{4}$ inch matched spruce sheathing, this extended up to the plates a distance of about twenty feet. The floor, stone, and brick walls were cemented, and after furrowing the sides above the brick wall to make an even surface, the sheathing of spruce was carried to the top of the silo. I put doors of matched boards on the first and second floors of the barn, and rough steps from the second floor to the top of silo, all of which cost $\$ 25.00$, and felt that the lumber would be worth \$15 for other purposes, in case the silo was a failure. I shall next build a silo of hemlock boards and cover the cracks with lath, as it costs less and lasts longer than spruse. 
My next business was to get the right kind of a cutter, and very likely I taxed the patience of some dealers by my questions, but I wanted a cutter that would cut rye, hay, and dry corn stalks, as well as the green corn fodder, and after careful investigation I decider that the Little Giant was the right article, and am happy to say that a thorough test has proven that my choice was a wise one, for the Ross Little Giant is correctly named and fully meets the published guarantee of its manufacturer.

The early frost (which was a severe one) of last fall laid its icy hand upon four acres of my corn fodder and left it as pale as death. I was in a fix. Silo and cutter ready, but the sweep power had not arrived, and every farmer knows liow quickly corn fodder becomes worthless after a heavy frosting. I set my men at work cutting it with bramble scythes and hauled it at once to the silo and begun to cut it up by hand, but fearing the effect of the frost, I deemed the work too slow and filled it into the silo both whole and cut. After all was in and carefully spread and trodden down, with the doors closed, and covered with tarred paper to keep them tight (here I made a mistake, for tarred paper injures the ensilage where it comes in contact with it), I covered it with two-inch planks, and then weighted it with eight inches of wall stones, and all was well. After a few days it began to settle and smell like an herb factory, owing to the weeds which were gathered with the corn, and when it had settled five or six feet it stopped and remained quiet until the 20th of October, when I opened it. Bear in mind that two sides were singie thickness of boards and no filling on the other sides. Under the planks, it was wet and sour about four inches deep, while between the planks it was not so wet and of a brighter color. I shall not use plank again, but shall cover the depth of a foot with poor hay and put my sacks of sand and stone on top of hay.

The ensilage was splendid, the pale frosted stalks had become a bright straw color and were juicy. I was happily surprised. I found that my cutter would cut it as well as if it were fresh and 
green. It has the sweet smell of ground apples with an alcoholic odor. My cattle soon learned to eat it, and indeed prefer it to good hay. I was anxious to make a thorough test and so stopped using grain for two weeks, then for a full month. I fed ensilage three times a day without hay or grain, carefully watching the effects, and failed to discover any signs of injury, but on the contrary found that my steck improved' sieadily. Since that time I have fed ensilage every day, and my cattle are all healthy and looking finely, and were never wintered better nor so cheaply.

I do not think that any fair-minded man can stand in front of my stock, and'see them leave good hay in their mangers in their anxiety to get the ensilage as soon as the silo door is opened, with their eager, wistful looks toward the point of interest, and see the condition of my cattle, and then condemn silos and ensilage.

I feed direct from the silo, taking the top, which is exposed to the air, and find the fodder which was cut finely kept in the best condition, as it packs closer, and I found by opening the doors so that I could examine the fodder from the top to bottom, that the closely packed was free from mold, while any openings left by loose packing contained a little mold.

Every farmer has some place on his farm where he can test this matter cheaply, and it will pay to do so. There can be no fixed rule in regard to the cost of raising the corn fodder, as that will vary with the soil, and every one must use his own resources to increase his crops. Remember that the double back furrow tells us that one piece of soil helps another piece to produce a better crop, and it is needless to tell farmers that the land must have manure to get the wished-for results.

As to seed, the Maryland white southern corn is the best, and can be bought of any grain dealer. I have tried it by the side of the best wonderful prolific varieties. In order to get the best crops it should be sown early, not in drills, but broadcast, and the inanure being spread and cut finely. I plowed them in together about three inches deep, then go over it with a bush. As soon as. 
the corn is fairly up, I go over the whole piece with a light onehorse harrow, having the teeth slanting a little backwards, and thus kill the tirst crop of weeds without injury to the corn.

On sod I hedge it in rows three feet apart, using the Planet, Jr., and with this machine, I can furrow, cover, roll down, cultivate, and hoe my crops with the horse.

Experience is better than theory, and I find that I can double my stock on this farm by the aid of silos and ensilage, for I can raise and store five tons of fodder corn at the cost of one ton of hay put into the barn.

Yours truly,

J. A. PERRY.

E. W. Ross \& Co.,

Bridgeton, N. J., March 13, 1884.

Gentlemen:-Your request in regard to my experience with ensilage and manner of constructing silos, etc., at hand. Will endeavor to give it briefly:

The corn is sown in drills three feet apart, tbree bushels per acre.

The ground that will produce fifty bushels corn per acre in an average season, will produce about thirty-five tons of green fodder. The ground that is to be used for ensilage should be made very rich; then it will produce twice that amount if the season is not too dry.

Both theory and practice teach that ensilage is not a complete food for cattle. It is deficient in albuminoids, and some concentrated, nitrogenous food should be fed with it, as corn meal, oil cake, or cotton-seed nieal, containing albuminoids to excess.

As to constructing silos, almost any way will answer, so they are built to exclude the air from the fodder. Mine is rectangular, about half above and half below ground; would prefer it above ground, but it is much more difficult to fill and weight. I do not 
think that ensilage will take the place of clover hay entirely, but it is a valuable adjunct and is a great saving of it.

I write these few lines as my short experience with ensilage, hoping that they may benefit some one.

Yours respectfully,

CHAS. J. FITHIA N.

Waddington, N. Y., March 17, 1884.

Messrs. E. W. Ross \& Co.,

Dear Sirs: - In reply to yours of the 16 th inst.. I will state to you as near as I can all the particulars concerning my silos. I cannot tell what it cost per ton to raise it, to get it in or store it, because a good deai of what corn I sowed was drowned out, so that I could not accurately estimate the number of acres of corn. I will now state the number of loads of clover, corn and oats, etc., that I put in silos. First silo I put in twenty-four loads of green clover.

It takes four men to fill a silo and do it justice: one to put on table, one to feed the cutter, one to spread in silo, and one to tramp in silo; and if there are two men in the silo tramping it is all the better, because the more it is tramped the less weight it takes. I am now feeding the clover, feeding two feeds a day of ensilage, and one feed a day of hay and straw cut half and half. I feed the dry feed about noon, the ensilage I feed early A. x. and late P. M. My other silos I put in fourteen loads of corn, three loads clover, four loads of oats, all these perfectly green, tramped it well, put on the weights, which was stone about ten inches deep, on and all over the silo. The silo settled down to about one-half. My other silo was filled, weights put on same as other; it settled three feet. "When they were both opened, were found to be slightly 
moldy on top, in some places tro inches, and in some places near edge six inches. But it did not smell bad, and when well mixed with the good ensilage, they ate it all, so there was no waste. My covering was hemlock lumber, two layers, breaking joints, and they were cut about one inch or inch and one-half, shorter than silo to allow for settling. I opened them in sections, cutting right down from top to bottom, then when down to the bottom I took off another section of two or three feet and cut down the same way. Now for a description of the silos which I built in my barn mow; two silos, thirteen feet above ground. They do not go below ground. Width of each silo $11 \times 15$ feet long inside. A mount of lumber used 7,840 feet; this includes $2 \times 6$ scantling, and hemlock, and tongued and grooved spruce. I purchased my lumber for $\$ 10$ per thousand. I put the studs sixteen inches apart. I used tarred paper $32^{\prime \prime}$ wide. I first tacked on the tar paper which would just cover three studs,_-put on the tar paper perpendicular. That leaves a hollow wall of six inches between outside wall and paper, - outside of silo single boarded with tongued and grooved spruce lumber. I then put on strips on each stud inside one inch thick by two inches wide, right on the top of the tar paper. Then I boarded it again horizontal leaving another hollow wall of one inch. I then papered again with tarred paper and then boarded again perpendicular with tongued and grooved lumber: My reason for boarding perpendicular is this: so there will be no obstruction to the cover when settling.

I would not approve of screws instead of stone for weight, simply because it is not a steady, continual pressure like stone, and as I have just stated, three thickness of boards and two of tar paper. The partition between the silo contains two thicknesses of boards and one of tar paper. The partition is boarded horizontal on one side of the studs and perpendicular on the other. The silos are well underpinned inside and out, and a good lot of mortar used, especially on inside, to keep out the air and frost. The bottom of my silo is one layer of stone six inches deep, all covered 
with sand, but intend to cement them both this year, because cement will hold the moisture and be much cleaner. I make a dormer-window in the roof over the partition between the silos and have a spout to slide it either way from the carrier. The doors for taking out the ensilage are made large enough to take out a two-bushel basketful of feed. I have two such doors one above the other in each silo, and in each door-frame three doors and two hollow walls. It took five days to fill the first silo, working about six hours a day; four men and one team for that length of time.

The second silo took three days to fill. Filled a little more than half full, one team and four men. We immediately put on the cover and then the stone. We don't know how much weight to the square foot. But I think it was about ten inches deep. I sowed corn of the southern sweet variety. I sowed in the drill; but, as I said before, the most of the crop was a failure. The corn made splendid ensilage; very jucy, but slightly tarnished; cows milked splendidly.

I will now tell you how well my cows milked on the corn. Last fall, in October; 1883, I got more pounds of milk from eight cows fed on two feeds of corn ensilage per day and one feed of dry fodder, than my neighbor got from seventeen head fed on unthrashed oats cut green, which is considered good fodder, especially for milk. These are positive facts. I now will give you an idea of how my cows are milking now-in March.

In one day, from two cows and one two year-old, and one threeyear-old, four in all. They average all the time, every day, between seventy and eighty pounds per day. This is certainly a good average; if they were.all old cows they would average much more. I tried my cows with ensilage and first-class hay, to see which they would prefer. I place ensilage in their manger, and put on the top of it first-class hay; of course they would smell the ensilage through the hay, and the result was they would not eat a mouthful of hay until they deroured all their ensilage. I 
know it to be the best feed for cows, and especially milch cows, on record. It is far ahead of first-class hay, three feeds a day, and two big messes of shorts, one feed or mash A. M., and the other P. M.

The carpenter-work cost about thirty dollars; tar-paper, ten dollars; nails, five dollars. You can see my expenses on building these are comparatively small. You know what my ensilage cutter cost, and my horse-power is worth $\$ 75.00$. I believe any one having silos must have very warm cow-stables, ensilage being so much like summer feed, etc.

My cows are all fat and in good order, and the all-clover ensilage they are feeding on now is, in my opinion, far superior to corn ensilage for milk. The milk is very rich and our butter brings the highest price in town.

You can take my word for it, that the No. 14 a ensilage-cutter I purchased of you is a first-class cutter in every respect. It cuts dry feed equally as well as green, and also the chain carrier, which is eighteen feet in length, works like a charm, and takes comparatively little power to run it. I use a two-horse power. I can cut ensilage as fast as two teams can draw, and cut, elevate it. spread, tramp, etc., all at the same time. I feed one bushel of ensilage twice a day to each cow; that is, on an average. Some cows eat more than others; they get only what they eat up clean. A bushel of clover ensilage weighs about twenty-seven or twenty-eight pounds, and corn of the same bulk weighs near or between thirtyfive and forty pounds. I cut in one-half inch lengths. I can most cheerfully recommend your ensilage cutter and carrier, etc, to the public, as a first-class machine in every respect. I intend to build another silo the coming season. It will be about thirteen feet high, and sixteen feet long, by sixteen feet wide. I never feed the horses ensilage, but am convinced they would do as well on it as the cows. Some of the cows, only one or two of them out of the herd, I had to teach to eat the corn ensilage; they were a day or two before they seemed to know what it was. I just shook 
a little meal on it, and they soon would eat it without the meal, and now they are, if anything, fonder of it than the rest.

Some gentleman whom I have read about, who has been experimenting with ensilage, complains of its scouring the stock. but it has done nothing of the kind with mine. If it did, I would feed more moderately of ensilage and a little more of dry feed; common ashes, one handful in a mash of any kind, is a sure cure for scours. If the first handful don't cure. the second or third mash certainly will. My sheep like ensilage well. Also, the hogs and pigs. I pour boiling water on what I feed the swine, and also mix a very little shorts or meal in it, and they eat it with a relish. and are in good condition. I am sorry I cannot give you what it cost per ton, but you can figure for yourself, from the time I told you it took to fill them. I gave you the number of men, horses, etc., employed filling; man and team are worth about $\$ 3.00$ per day, ten hours, and men $\$ 1.25$ and board.

This testimonial of mine you can print the most important part, or the whole of it if you wish, and any time you wish to know how I succeed, in the future, in this new mode of farming, I will be pleased to explain to you. You must not forget to send me a copy of your ensilage books when you get them from the press. If you wish me to be agent in this part send me the particulars regarding agents' territory, etc., and agents' commission, etc. I hope this will be of benefit to my fellow man and to you. If there are any more particulars concerning the silos I have just keen writing about, let me know, and I will explain. I am

Respectfully yours,

HENRY COLBURN. 
Pierrepont Manor, N. Y., February 4, 1884.

E. W. Ross \& Co.,

Gentlemen:-Yours at hand in regard to ensilage. I submit what my experience has been so far the present winter. My silo is built in my barn, which was constructed last summer. The barn is 112 $\mathrm{x} 56$ feet, having a manure cellar $26 \times 112$ feet, under where my cows stand, and two rows of cows, which occupy with the allowance for feeding. etc., thirty-five feet, in fropt of which is my silo, $19 \times 48$ inside, bottom on level with cows, and feeding door is front of one row, and silo extending up into barn twenty feet high; an entrance floor on each end of silo on floor above cows. My silo frame is made of $8 \times 8$ posts framed into a sill set into the ground, and upper end into beams of the barn fourteen feet apart, and girts between these posts $4 \times 8$, and 3 feet apart. I then placed two-inch plank up and down on inside, and covered the planks weil with coal-tar paper of good thickness, and covered the paper with hemlock boards, making joints as well as possible without planing. The bottom was made of gravel and two barrels of cement packed into it two inches deep, and then covered with a thin grout of water, lime, sard, and gravel, about two inches thick, and allowed to harden before using, several weeks. The lumber used was less than 10,000 feet of hemlock, at $\$ 3.00$ per thousand, and counting labor, cement, paper, lumber and all, the silo did not exceed $\$ 125.00$, and its capacity is about 450 tons, or about 100 cattle for seven months. I sowed first season about eleven acres, seven of which was Egyptian sweet corn, and four of Blout's Prolific white corn. Owing to circumstances, none of it was hoed, only cultivated once, and was hurt to some extent by frost; measured at fifty-five pounds per fuot. 220 tons when pressed in silo. The 13lout's Prolific corn was much superior to sweet corn in size, and appeared when put in silo to contain nearly as much sugar. I planted in drills twenty-seven inches apart, use Bradley's ammoniated bone at about two barrels par acre, in drill, cut the fodder with reaper, and used three teams and five men to get it to one of 
E. W. Ross \& Co.'s No. 16 ensilage chitters, with a twenty fcet elevator which carried it over beam into silo. It took two men to feed and one on table, and cut a ton in six minutes; used a sixhorse engine, and about forty pounds of steam; put in corn in about $3 \frac{1}{2}$ days, and counting all expense, cost seventy cents per ton to put in use, and lahor on land seventy cents more, making $\$ 1.40$ per ton in silos. Covered with plank and then threw on stone, estimated at 100 lbs. to the square foot, which took two men and team two days.

I opened and commenced feeding, November 5th. I fed as soon as the cattle would eat it freely, $40 \mathrm{lbs}$. each per day in two feeds, morning and noon, and a light foddering of hay at night; used one pint of pea-meal per day, and my cows increased their milk $100 \mathrm{lbs}$. per day in four weeks; increased the grain to one quart per day of pea and bean meal after first month. Shall have enough ensilage to feed sixty-six head of cattle from November 5th to-April 1st, with one foddering of hay and one quart of grain per day from eleven acres of land and at a cost of not $\$ 300.00$ for the corn, $\$ 150.00$ for grain, $\$ 200.00$ for hay, total $\$ 650.00$ for sixty-six head, which can be lessened by feeding more ensilage and less hay, and cost of ensilage by filling silo with less help and using more time. My caitle are perfectly healthy, and crazy for their feed, and if they had what ensilage they would eat at two feeds they would not eat the hay.

I consider a wooden silo safe and will last several years, when the inside boards can be removed, the paper keeping the outside plank sound; do not think woolen silos are as liable to freeze on sides, as the wood is a non-conductor, and a sudden cold storm will not penetrate.

Have fed a four-year olı short-horn bull on ensilage alone, without grain or water, and he has done well and is in fine condition. Shall increase my average number of cattle, and think I can keep double as many on same farm as was ever wintered on it, without extra expense.

Yours truly,

W. H. GRENELL. 
New Mrlford, February 15, 1884.

E. W. Ross \& Co., Fulton, N. Y.,

Gentlemen:-Your tavor was duly received. In reply I would say that I have had one year's experience with ensilage.

Last spring I built a silc with cement walls and floor, twentytwo feet long, and fifteen feet wide, and ten feet high. Over this I erected a frame building with posts six feet high, and planked up the inside even with the inner walls of the cement so as to make a total depth of fourteen or fifteen feet. The silo opens into the basement of the barn, and the walls are chiefly under ground. It was built after the manner described in Bailey's Book on Ensilage, by fixing vertical timbers about sixteen inches from the banks of the excavation, putting a tier of plank against these all around, and filling the space with cement, bedding in while wet as many cobble stones as possible; as each layer became sufficiently dry, the planks were raised and another added until the wall was of the requisite height. When it reached the surface, supports were of course placed on the outside also. .

The cement was mixed with sand or fine gravel, in the proportion of one to six, and about 35 bbls. were used. The walls are as hard as a rock and look likely to stand for ages. The total cost, including superstructure, and allowing tor labor and team work, was not far from $\$ 150.00$. The latter part of August, the silo was filled to the top of the cement, with the corn grown on some four acres, cut into $\frac{3}{4}$ inches in length. This settled under pressure to a depth of seven feet. The corn was sowed in drills, and cultivator run through it twice without hoeing. Of the exact amount of labor expended in raising I kept no account. Estimating the quantity at sixty tons, the cost of transferring from the fields as it stood to the silo cut and weighted, with reasonable al. lowance for wear of cutter and engine, was about $\$ 1.00$ per ton.

The silo was opened the first of November and its contents found to be in an excellent state of preservation, of an olive color and fragrant smeli. Since then, I have fed it once a day to my 
thirty head of imported Holstein and other cattle, and part of the time to about the same number of pure blood Suuthdown sheep. They ate it greedily from the first, and have thriven finely upon it without extra allowance of grain, as a pariial substitute for dry feed. I am satisfied that it is not merely economical for the owner, but better for the stcck. Beyond that I have never experimented, but if I had enough to last, I should substitute it further. It is perfectly palatable, sweet, and wholesome, and I know of no reason why it could not serve for two meals a day as well as one. In that case, one would simply need to feed more cotton-seed and corn-ineal and less bran, in order to keep as nearly as before to the so-called perfect ration.

But I do not wish to enter the field of argument. I have sim. ply to add that I built the best silo I knew how. From the begin: ning to the end, I sought to fulfill all the conditions of success, and not only did I provide a good receptacle for the corn, but I put good corn into it. when it was at the right stage of maturity, and before it was half spoiled by frost. I determined to give the system a fair trial, and then if it failed, it would not be my fault, but the fault of the system. The result is that nearly every person who has examined muy ensilage, says that it is the best be has ever seen.

It may be that wooden silos built above ground, as you suggest, will answer every purpose. That must be left to the experience of those who have tried them to show.

My silo excluded the air so perfectly, that the amount of spoiled ensilage practicaly amounts to nothing. It would not exceed a bushel or two in all, and that owing to the impossibility of making a hermetically tight covering. In my judgment the slight additional expense of concrete, at the outset, is more than counter. balanced by its greater durability and the greater certainty of the perfect preservation of its contents. I hare ro desire nor interest, gentlemen, to influence any man's opinion, either on the main question or the methods of its application, but in response to your 
request, have briefly stated my own experience. That experience enables me to say, that the capital I expended in a silo was the best investment I have ever made.

Very truly yours,

E. B. MARSH.

E. W. Ross \& Co.,

Conter Rutland, Vt., February 8, 1884.

Gentlemen:-Your much esteemed favor of the 26th ult., is at hand. In repiy, practically I can say little from experience on ensilage. Two years since I built a silo on my farm in New Hampshire, but that is seventy miles away from me and I go there only two or three times a year, consequently have not watched results. My man on the farm thought so well of the first one that I built the second one last year. I can only say that I built of wood and quite cheaply. The ensilage has come out each year in splendid condition. Some adjoining my farm built of stone and cement at a much greater cost. More satisfactory results have been had from my silo, built mostly above ground, and entirely of wood. I took one end of my barn and lined up about eighteen feet with plank. The cost of my silos did not exceed $\$ 50.00$ each. Sizes were twenty feet long, fourteen feet wide, eighteen feet deep. I will only add that I think silos have come to stay; and I fully believe in them. I wish I could write you results obtained from experience and practical knowledge. I should much like one of your books when out. I think another fall I may want a cutter. Hastily yours,

W. A. JOHNSON. 


\section{7}

Monmouth Juncrion, N. J., February, 1884.

E. W. Ross \& Co.,

As to the subject of ensilage, I am of the opinion that farmers are mainly hampered by two great considerations, those of prejudice and ignorance. Prejudice, in that they are firmly persuaded it is a good thing, but persistently refuse to try its great and lasting benefits-and ignorance, because they allow their old time customs to dominate their every day lives to the exclusion of great and practical results. After an experience both in the county "Middlesex" and outside the State, I am of the opinion that the silo, in a great many instances, is made toc costly. Of course, with large capital șuch a course is of no moment, but to the small farmer-to whom I verily believe the Ross cutter is an estimable blessing-cost of course must be a consideration. My plan is to dig a pit (according, of course, to the ensilage grown) of from twelve to twenty feet in depth, with a breadth of about half the same number of feet. The material can the be introduced, and after the pit is filled a screw-jack can be used, taking care of course that the pitsides are lined with plank, and then a temporary flooring being in place, the whole mass can be firmly packed, the tighter the better. Cost per ton, too, is so excessively low that it need not alarm the most penurious.

As to its results, ensilage food is of itself doubly nutritive in the winter, and is far ahead of ground fooc, and careful chemical analysis shows that the waste of the various nitrogenous and carbon-giving elements are little or nothing.

These crude and informal remarks are given and are based upon the honest conception of the writer who cannot close without $a^{\prime}$ reference to the kind of cutters that should be employed. I have watched the various cutters that have been floated, but unhesitatingly award the palm to the Koss cutters and carriers. Simplicity of construction, durability, added to a never-failing satisfaction in working, are a few of their distinctive merits.

DOUGLAS DEMEYRICH, Country Eaitor "Home N'ews." 
Washington, February 2.

Messre. E. W. Ross \& Co.,

Gentlemen:-Your favor of the 25th, after sundry forwardings, reaches me to day.

I can give you no valuable figures on the cost of a ton of ensilage in silo, because my assistants dia not keep their accounts with proper detail, the first year, and this year the corn yield was too short for a just estimate. As far as I can judge, wet curing by ensilaging is a safer method than dry curing.

The quality of the ensilage depends on the condition of the crop harvested. I have preserved excellently full-grown corn which was badly frost-bitten in a wooden silo; corn grown only to about three feet in height, when frost-bitten, is not nearly so good, though preserved in a stone silo under great weight.

The silo does not improve, it preserves the younger plants with more danger than the older ones. Experience alone will teach the farmer the difference between good and poor ensilage.

The quality is as easy to distinguish as the quality of hay. In laying out cattle-bains, the body of the distributing wagon should be six inches to a foot above top of manger, the bottom of silo should be six inches to a foot above the top of the wagon-box. It costs practically nothing to raise the crop over the top of silo, as the engine that runs your No. 18, Giant, making an average of one hundred loads a day, did cut thirty-five loads in two hours. Your No. 18, Giant, will cut a load of stalks in 2 minutes $12 \frac{1}{2}$ seconds, and I do not think any more men could have been used to advantage. Six minutes a load is the average time taken to drive a load up to the platform, unload and go away.

A stone silo I am convinced is cheaper than a wooden one. My stone silo cost about $\$ 2.50$ per ton capacity; the wooden one about $\$ 1.50$ per ton capacity; the stone one ought not to rot, the wooden one cannot he expected to last five years. Silos should be as deep as possible. Fourteen feet two inches is as good a width as any; a sixteen-toot plank is a trifle heavy. Planks can be got ten feet, 
twelve feet, fourteen feet, sixteen feet. About two inches play is needed to prevent jamming.

The beginner should see several silos before building his own. By careful study a good designer can sare the practicing farmer imménse labor bills.

Sixty dollars is the interest of $\$ 1,000$. Yet $\$ 60$ is two months' wages for a man. How many farmers will hesitate to build for $\$ 500$, where they would not hesitate to employ another man? The advantage of the silo is security in harvesting and labor saved in feeding.

If the silo and barn are not well designed they will cause severe loss instead of a handsome profit. I do not consider ensilage only proper feed.

Ycurs truly,

HERBERT WADSWORTH.

E. W. Ross \& Co.,

Cooperstown, N. Y, February 6, 1884.

Dear Sirs:-Yours of the $2 \mathrm{~d}$ at hand. In reply will say that I don't feel competent to write an article for your book. I filled one of my silos last season for the first time. The early frost cut my corn very bad; some people thought that the crop was not worth cutting and putting into the silo. I cut it with my reaper; one team to cut it, two teams and three wagons to draw it to the silo. One two-horse-power to run the No. $14 \mathrm{~A}$ Ross cutter. We put in three loads per hour. It took three men one-half day to fill or cut all the fodder corn off of ten acres, by estimate 80 to 100 tons. I opened the silo January 1, 1884. The ensilage his kept well, and is more than satisfactory to my stock and to myself. I want to fill all my silos this next season. I think it best to put on plenty of stone for weight. That you want to recommend 
strong in your book. I built with stone. I paid 46 cents a perch for laying the stone, I furnishing stone, lime, and tending mason. I have two silos $33 \frac{1}{2}$ feet $\times 12$; one $20 \times 12$; one $12 \times 12$, all thirteen feet deep; the partition-wall eighteen inches thick, and sidewalls two feet thick, all plastered with cement, side and bottom. The bottom of my silo was rock. I put in small stone first, then pounded up stone fine to make it smooth, the plastered over the bottom. If there is any water to run out of the rock-bottom, the drain in the small stone will take it off. My plan is, if a barn or silo is worth building, it is best to do it well. I would not advise any slip-shod of a farmer to build a silo.

Wood, if air tight, will keop the fodder as well, below as above ground. I will give you the basement or ground plan of my barn and silo. The bottom of the silo is fourteen inches below the stable floor, so that it is easy to feed the stock. My cows give me more milk since I fed them with ensilage morning and night. I make butter winter and summer. I think that the milk and butter is better color and flavored better since I have fed the ensilage. The cows milk better, give down the milk the same as they do to grass, don't drink as much water. I feed hay at noon, for my ensilage will not hold out to the end of the season if I feed it too fast. .

Yours truly,

\section{MARCUS FIELD.}

E. W. Ross \& Co., Fulton, N. Y.,

Chicago, January 31, 1884 .

Gentlemen :-Your letter of 29 th inst. is at hand. I am very sorry I am unable to comply with your wishes in regard to ensilage, silos, etc., as I have had no experience with it. I have used your cutter only in cutting dry feed, stalks, hay, etc., and will give my opinion in the use of it for this purpose, if you 
wish. But I suppose you have all you care for in this way. I hope you will favor me with one of your books when reacly for distribution, as I am sure it will be of much value. I wili be glad to assist you in any way in my power, for I want information, as I have about twelve square miles; which has been put under the plow within the last ten years, and now am putting it into a thoronghbred stock farm.

Last spring I went to England, and chartered one of the largest iron steamships that cross with cattle, and loaded both decks with 306 head of thoronghbred pedigree Hereford cattle; all females but ten, and are now on my farm doing well.

Now you will see that I am in need of help in obtaining knowledge, to care for what I have and what I expect to come. Although I commenced farming when thirteen years of age and am now fifty-one, yet I find I have much to learn.

Tery truly yours,

505 Monroe street, Chicago, Ill.

\section{CHAS. W. COOK.}

Union Springs, N. Y., February, 1884.

E. W. Ross \& Co.,

Gentlemen:-I have used ensilage for some years by way of experiment and for a small family. The silo occupies one end of a barn basement, and will hold about thirty tons, it was made at a cost of less than thirty dollars, by merely plastering two sides, and making solid plank partitions lined outside with building paper on the other two sides, the cow stalls are on the same level, and the animals are easily supplied through the plank door. The fresh stalks are drawn to the floor above, cut half an inch long with a two-horse Ross power cutter and a few tons filled in each day. It is better to fill moderately so as to promote some fermentation, 
which cooks the ensilage and makes it better, than if converted to vinegar at a lower temperature. The silo is weighted as usual with stone on plank, half a ton or more to a square yard. For removing the ensilage, the stones are easily placed on a broad, solid shelf surrounding the silo; this I find much simpler, easier, and better than any other kind of pressure. I do all the work with a two-horse team and the labor of two men. They cut the stalks in the field with sickles, placing them at one operation on the low wagon and drawing about a ton at a time. One of the Ross small power cutter (No. 11), driven by the two horses, which are taken from the wagon, will cut a ton in twenty minutes, but when briskly driven it has been done in less than ten minutes.

I find this mode of preparing fodder to possess several advantages, and on the whole I prefer it to any other. The stalks may be cut, drawn in and chopped in any weather except a pouring rain. The labor of chopping the fresh, succulent stalks is only one-half as much as cutting dry fodder; the space they occupy in the silo is several times less than by the common way of storing in barns, and my neighbors are often astonished at the large amount packed solid in so small a space.

The cows prefer the ensilage to dry food. Keep in better condition and give rather more milk. An important saving of labor is effected by entirely avoiding placing the stalks in shocks, and then there is no danger of the fodder spoiling in heavy rains.

I have not made a rigid estimate of the cost of ensilage by the ton. On rich soil twenty tons of green fodder may be raised on an acre in the average of seasons.

The past wet summer gave me twenty-eight tons. In very dry summers I have had only fourteen or fifteen tons.

But much depends on the richness of soil, and it is much cheaper to raise heavy crops with plenty of manure. The large southern sweet corn, the seed of which I obtain yearly from Burrell \& s Whitman, Little Falls, N. Y., yields nearly one-half more than our small northern varieties. The cost of the fodder ready to cut 
ought, therefore, not to be more than one dollar a ton; drawing and filling in would not be greater, probably a little less.

I have found by experiment that cutting dry fodder half an inch or less in length doubles its value for feeding, as compared with the common mode of feeding it uncut, and had adopted this mode before employing the silo. The latter is a still further im. provement.

An important additional advantage is gained by either mode, besides economy in feeding by the increased value of the manure, which is short, ready to spread at any time, and is free from the long fibre so troublesome in common cornstalk manure.

J. J. THOMAS.

Messes. E. W. Ross \& Co.,

Baltic, Cons., February 5, 1884.

Gentlemen:-In answer to your letter of 30th ultimo, asking a statement of my experience in ensilage, etc., I will say that for over two years back I made it a duty to enquire into ensilage, and have taken great pains to ascertain from books written on the subject, and from parties that had built silos, whether it was profitable to build silos and raise corn for ensilage. Not wishing to farm it for the mere fancy of doing it, I was desirous to make farming a success financially.

After gathering all possible information for and against it, I finally resolved, last spring, to build a silo and raise corn to fill it.

I built a silo partly under ground and partly above ground, so that the top of my silo was one foot above the floor of my barn, $45 \times 24$ feet, divided in three parts, each measuring $13 \times 20$ feet at bottom, and $13 \frac{8}{12} \times 20 \frac{8}{12}$ feet at top, and 16 feet deep. As you will see by the measurement that my walls were made with 4 -inch battening on the 16 feet so as to insure a perfect exclusion of air 
in pressing the mass with stones, putting about $400 \mathrm{lbs}$. to the square foot.

My silo is built of common field stones which cost me the cart. age (about 150 rods), laid in lime mortar, the wall being 24 inches thick at bottom, and 16 inches at top, and are fastened inside with mortar, made of one part lime, 5 parts cement, and 12 parts sand for the sides, and bottom of one part cement, 3 parts sand, and 2 parts gravel. and cost $\$ 392.87$, not counting cartage of stones and sand, and holds when filled 240 tons.

Although it had hardly time to dry before I put in my ensilage, I find now (as I have emptied) it is in very good condition, and feel confident that it will last a century or more.

For corn I sowed Southern Dent in drills 40 inches apart, with the Albany corn planter, from June 6th to 12 th, putting superphosphate in the drills, with the attachment in the planter, $300 \mathrm{lbs}$. to the acre, but owing to different causes and particularly to drouth, it did not grow as well as I expected. I raised 160 tons on 10 acres, and it was slightly damaged by frost. I begun to put in my ensilage on September 6tla, and finished the 12th, taking three days in one week and three in another to fill two parts or 160 tons, but as it was the first time any of my men had done this kind of work, it could be done quicker. I use the Ross Little Giant Cutter No. 14A, with a two-horse tread power with $5 \frac{1}{2}$ feet diameter drive wheel. It did the work very nicely and cut the whole 160 tons without grinding the knives, a remarkable thing to compare to what 1 hear of other kinds of cutters.

I begun to feed my ensilage November 8 th, found it in a nice condition, and fully up to my expectations, and found that my cows ate it very well, some the first time it was given to them, and all after two or three feeds. My cows have gained in milk, quantity and quality, and I have made and am now making as good butter (color and flavor) as I have ever made in summer. Milking is done before feeding so as to be sure that no taste of any kind of feed is imparted to the milk, and althongh working under 
many disadvantages, my ensilage did not cost me over $\$ 3.00$ per ton, and I am confident I can raise it much less another year. All I regret is that I did not have enough to fill all three of my silos, and that it did not feed my twenty-five milch cows and seven head of young stock for more than five months, giving them a little meal and shorts with it morning and night, and feeding a little hay at noon each day; but I hope that next year I will raise enough corn to fill all up, if manure and fertilizer will help.

Very truly yours,

J. H. WOISARD.

E. W. Ross \& Co.,

Branford, Conn., February 4, 1884.

Gentlemen:-We are in receipt of yours of January 29th, asking us to send you a statement of our experience with ensilage, the way we built our silo, and our opinion in general on the system. We built our silo in one of the bays of our barn, it is $10 \times$ 16-16 feet deep. We dug down six feet and stoned it up and cemented it smooth as the side of a room.

We then laid sills on the stone-work, built a frame ten feet high, and covered it on the inside with one inch matched boards, two thicknesses, breaking joints as we do with shingles. We then gave the boards a coat of coal tar to fill the cracks, making it perfectly air tight. The silo when completed cost $\$ 65.00$.

We planted three acres of southern white corn in rows three feet wide, with the hills fifteen inches apart in the row. We began to fill our silo August 1st; it required the aid of ten men and four horses two and one-half days to fill it. We cut the ensilage onehalf inch long with the No. 13 Little Giant Cutter, which we purchased of you, driven by a Cobleskill horse-power; it made lively work for three men to feed the cutter. We are well pleased 
with both, power and cutter, and would advise any one going into the ensilage system to try a Cobleskill Power and Ross Cutter. After. we had filled the silo, we covered it with tarred felt and two-inch plank, upon which we put about ten ton of stones.

We opened the silo December 5, 1883, and found the fodder as green and sweet as when first put in. We have been feeding our milch cows since December 5th, all they will eat, with about six quarts of wheat shorts a day, and they never looked or did so well as at the present time.

Our milk is sold every day in New Haven to some of the first families, and we have not heard one word of fault yet. Parties in this vicinity who have silos and cut their fodder one and one-half inch long, admit that our ensilage is better than theirs, and they will cut it one-half inch next season.

On the whole we are more than pleased with our ensilage fodder. and think that a visit to our barn will convince those who are prejudiced against ensilage that it is a valuable winter feed for milch cows. We are so well pleased with it that we shall build an acidition to our silo $10 \times 16$ in the spring.

We are satisfied that there are three things necessary to be successful with ensilage: first, a good silo; second, the fodder must be cut at the right time, that is, when it is in the milk; third, it must be properly weighted.

Yours very respectfully,

J. H. \& F. E. BEACH.

E. W. Ross \& Co.,

Dublin, N. H., February 9, 1884.

Gentiemen:-At your request, I will make a few statements in regard to my silo and my experience with ensilage. I have been a great believer in this system of storing fodder, for two or 
three years, and was determined to try it thoroughly, but on rather a small scale at first. My silo is built in one corner of the barn cellar, and is 9 feet deep below the barn floor, and $9 \times 14$ feet on the inside. It was built last June, and I estimated that $\$ 100.00$ would cover the whole experise.

I have no doubt but that a wooden silo might have been built for much less money, but I prefer to have the bottom part built of cement. I commenced by laying a drain covered with flat stones from the bottom of the cellar wall, starting in the corner and running under the silo and out from under the barn; this is to carry off any water that may collect round the wall, and make it dry under the silo. Then $\mathrm{I}$ dug ont the dirt and put in about 8 inches deep of little stones all over a place the size I wished to build the silo. I used 16 cakes of Norton's cement, which I bought of D. Roby \& Co., 280 Causeway street, Boston, Mass., a good reliable company. The cement was mixed three parts gravel to one of cement, the walls; which are one foot thick, have as many small stones packed in the cement as possible, and have a good job; to finish the bottom I covered the stones with cement mortar about three inches deep, and made it water-tight. I planted white southern corn, about one acre in all, about half of it was planted in drills, but we got it too thick; the rest was in hills and grew larger stalks. I think there is more danger of planting it too thick than not thick enough. The dry weather hurt my corn considerably, and then at last the frost nipped it, but I had some very good ensilage after all, much better than I expected. I used the Little Giant Ross Cutter No. 11, with a one-horse power; and cut the corn $\frac{1}{2}$ inch long. I think the Ross Cutter is far ahead of any other kind that I have seen. I put the corn into the silo about the first of September, and pressed it by raising a scaffold of hay, with two jack screws and bringing the weight on the corn. I had enough corn to fill the silo, and after it had settled a foot I filled it up again, then it settled two feet more, leaving the ensilage seven feet deep, when I opened it October 20th. It had kept 
splendidly. I have fed five bushels every day, and some clays six; at this rate I think it will last until the first of April. The cattle appear to like it as well as meal or the best of hay, and I have seen no bad results from it. I am satisfied that I cannot afford to do without ensilage, and intend to enlarge my silo the coming season by building it higher. I have read of folks that pressed their ensilage until the juice ran out in large qrantities, but I think that is wrong. The main point is to have the corn trod tighter round the edge of the silo, and then it does not need to be pressed very hard to have it keep well, according to my idea.

\section{Yours truly,}

CHAS. F. APPLETON.

New Brunswick, N. J., February j, 1884.

E. W. Ross \& Co.,

In reply to your inquiries about silos and ensilage, I reply briefly. I built two silos in the summer of 1881. Each $13 \times 19$, and 16 feet deep inside measurement; the walls are fifteen inches at bottom, six feet below surface of ground, and battened in at outside to twelve inches at top. I used concrete for the walls and bottom, made by mixing one barrel Rosendale cement and four and one-half barrels coarse, sharp gravelly sand.

In using this we bedded into the concrete, as the walls were going up, all the field stones we could get and have the concrete completely cover and fill so as to make solid work; the cost of these silos exclusive of covering was about $\$ 1.25$ per ton capacity, estimating fifty pounds to củbic foot. I made no charge to the silo for the field stone used, nor for the time in picking them up and bauling to silo. These charges belong to farm improvements, and the silo walls were as convenient as any place to dispose of them. 
If one has stone at hand I do not see how a silo could be built cheaper, certainly not if durability is considered. I have only used corn for ensilage, but cannot give cost for raising, but to put it into the silo including cutting up in the field and carting, the cost has been $75 \mathrm{c}$. to $80 \mathrm{c}$. per ton. I have had three years experience in feeding ensilage for milk and beef, and much prefer it to the same fodder cured by drying. Unquestionably the greatest objection to ensilage as usually preserved is an excess of acidity. To prevent or correct this, is now the greatest problem to solve, which the scientific and practical man must work ont together. That we are on the road to success in this direction, I fully believe.

Tery truly yours,

EDWIN ALLEN.

E. W. Ross \& Co.,

Adams, N. Y., February 5, 1884.

Gentlemen:-Your favor of the 2d, requesting me to give you my experience with ensilage, is received, and I cheerfully comply with your request.

In the summer of $1882, \mathrm{I}$ built a silo on the north side of my barn. Dimensions, fifty-four feet long, sixteen feet wide, and sixteen feet deep. We excavated about ten feet deep of earth, the bottom being two feet below a basement stable, this gave us ten feet in, and six feet out of the ground. The silo is built with lrmber, using $2 \times 6$ hemlock, placed flat one upon another from the bottom to the top, with a partition in the center, made of $2 \times 12$ plank laid flat as before; the object of laying the plank flat was to have the walls strong enough to resist pressure, and also to guard against frost. The side next to the barn is laid with $2 \times 4$ stuff. I found this plan much cheaper than stone and mortar, as I had no stone, without hauling some distance. 
I cannot give you the exact figures as to the cost of my silo, as the job was done in connection with other work, and during my absence from home. I paid for excavating, ten cents per cubic yard, and $\$ 9.00$ per M. for hemlock timber delivered. .I estimate the cost to be about $\$ 300.00$.

The capacity is supposed to be about 260 tons. In September I came home to superintend the work of putting into silo seven acres of corn that had been drilled in especially for ensilage I found on my arrival home that the walls of the silos were not finished. They were not made smooth as I expected, but were left in a rongh and uneven state.

As the help were all engaged, also machine for cutting, we userl your Little Giant. Cutter, No. 16,) and my time limited, we cut the corn into the silo in its unfinished condition.

The cutter did good work, and we put the corn in without much hindrance, except rain hindering us about a day. When ready to cover I could not obtain the right length lumber of any kind to cover with, and I used such as I could find, any and all lengths. I could not get a perfect cover. We weighted with barrels of sand, about 100 pounds per cubic foot. Owing to the uneven condition of the walls which resisted the pressure, and the bad covering the ensilage did not keep well, but the only spoiled ensilage was around the sides of the silo; at one end where the silo had been finished with smooth boards, the ensilage was in good condition. The quantity spoiled was about six inches in from sides; all through the center from top to bottom, the ensilage was in good condition, and the stock ate it with a relish as long as it lasted; the result of my first year's experience showed me that I must have smooth walls in order to have perfect pressure, and that the ensilage must be kept air tight. The result of my second year's trial of ensilage has proven more satisiactory. During the season the wall had been made smooth by being lined with matched and planed lumber, the ensilage was well trodden and packed as it came into the silo from the cutter. 
When all in we covered with plank cut to fit, and weighted same as before, and with loose sand about eight inches deep all around the sides of the silo to keep out air, sealed up the door of silo with water lime. Ensilage put in about the 25th September, and silo opened about the 15th November, and ensilage found to be in good condition. and keeping all right. At the time of opening silo the weight was all removed; this should not have been done, as ensilage must be kept weighted until required for feeding. The ensilage this winter has kept well, until quite recently, when some of it which had been a long time exposed with weights off was affected by the air. Only as much as is required for present use should be uncovered and the rest should be kept covered and weighted until wanted.

Stock like it and do well on it as a general thing. My corn was badly bitten by frost the past season, spoiling all the leaves, which has to a great extent affected the quality of the ensilage.

The cost of raising a crop of corn for ensilage is the same as for grain; the cost of putting corn into silo, is governed by circumstances, the quantity grown per acre, and the distance of silo from crop. I estimated I had about ninety tons from six and one half acres of ground, and cost about $\$ 1.40$ per ton to raise and put in silo. I think now I can raise corn and put in silo at a cost not to exceed $\$ 1.00$ per ton. One acre nearest the silo put in the first season, on which was twenty tons corn fodder, green, cost on a careful estimate ninety cents per ton to grow and put in silo.

Good soil, good seed, good tiilage, and a farorable season, will make cheap ensilage. I am wintering eighteen head of stock, two horses, six hogs. I have only thirty-two acres plowed land on a farm of sixty acres. Before I built my silo the farm would barely keep a half-dozen cows and team; now I know I can keep twenty-five corrs and a team the year round. Silos can be built much cheaper. and for much less money than mine; fifty to seventy-five cents per ton capacity ought to build of lumber that will keep ensilage.

My statement is quite lengthy, more so than I intended, and still 
much more might be said. I believe ensilage is a good healthy food for cattle, and the silo system for keeping stock should be generally adopted in this country; and I believe as good butter can be made from it as any other feed used in connection with grain. - Very respectfillly yours,

G. S. NOTT.

Ferry Cliff Farm, Bristol, R. I., March, 1884.

E. W. Ross \& ( Co.:

The conflicting reports regarding the preparation of, and the benefits to be derived from feeding ensilage, has made it difficult for an owner of live stock to determine whether he would do well to adopt the system or not. Some of its advocates have written as if green fodder might be saved by putting it into any kind of an enclosure, air tight or not, and applying pressure, little or much, as the operator might select, and there are those who would have us believe that stock might be fed upon the resulting fodder ad libitum, and that beef, mutton, and milk, would be produced for almost nothing, as the reward of this slip-shod husbandry.

It is not remarkable, as many have been influenced by this teaching, that failures have not been uncommon, nor can it be wondered at that those who are willing to decry the silo as a means of preserving green fodder, may be found in many quarters. The process might with reason ask "to be saved from its friends." The process of preserving fodder by putting it into a silo and promptly applying heavy weight, is, in fact, accomplishing on a large scale what is done in canning vegetables.

It is too late now for any one to pronounce canning a failure, because a certain lot of tomatoes sealed up twenty-four hours after filling, are found spoiled upon subsequent opening.

The construction of the silo may be ever so simple, and its sides 
may be made of any convenient material, but its walis must be plumb, smooth, and it must be air and water-tight, and strong enough to withstand the side-thrust which result from the weight of the fodder, and that which is put upon it to produce pressure. In most cases it will be, in the end, cheaper to build the silo walls of stone, or brick, or concrete, cementing smoothly the sides and the bottom. not forgetting to drain the ground when that is necessary. It is a very common mistake to make the silo too large. It is better to build several small ones rather than one as large as all combined. The largest silo should have no greater capacity than can be filled and weighted within two days. Beside the absolute certainty of saving fodder put away with this promptness when sufficiently weighted, there is the added advantage of taking off the daily allowance from the entire upper surface rather than cutting down at one end of a large silo. In the former case, there is no part of the fodder exposed long before it is used.

A silo filled with corn cut immediately upon being brought from the field, and trodden as the filling progresses, which is topped off and weighted with 300 lns. to the square foot, within thirty-six hours after the filling has begun, will turn out good. juicy, bright, healthful fodder with absolute certainty. I will not say that good ensilage has not been made, that bas not had different treatment, but to proceed in this manner is sound theoretically, and the results may be confidently relied upon.

It is not remarkable that a food so easily prepared in large quantities which nine cows out of ten will in winter time eat, in preference to the best June cut hay that can be put before them, should be given with a free hand. I believe that to this abuse of ensilage more than anything else is due the opposition that some give to this method of feeding. As an exclusive diet it is probably no better for a cow than sour-krout and beer would be for a man, but fed in small quantites it supplies a useful variety of diet, and provides a succulent food at a season when such food is scarce, and very useful. In this respect it fills very much the 
same place that roots occupy. Theoreticaily the chemist may tell us that well-cured hay differs from grass in that its moisture (water) has been evaporated. Were this strictly true from the herdsman's standpoint, $i$. e., would only be necessary to add moisture to hay at the time of feeding to make it equivalert to June grass, and yet any practical man knows this is not the case, and that butter and milk made from hay, differs most essentially, both in color and quality, from that made when the cow is fed on grass. The difference between the feeding value of dried corn fodder, and corn preserved in a silo, is probably greater than that known to exist between hay and grass. Practically it is very difficult to cure corn fodder, cut before the grain has ripened, when much of the succulence and nutrition ultimately to go with the ripened grain is still in the stalk and must be put to the credit of the silo: that it takes the plant at this stage and preserves it with certainty for future use. This process of preparing ensilage, however, has an improving effect upon the plant. The fodder thus treated, owing to the fermentation which has taken place, has been rendered more digestible, and the feeding value of any nutrient is in proportion to the ease and the rapidity with which it can be appropriated to the needs of the body. A degree of acidity is not incompatible with the good quality and digestibility of the ensilage, indeed, the gastric juice is complete and in operation as a digestion fluid if deprived of its proportion of muriatic acid.

That ensilage should be more easily digested, and therefore more nutritions, than either fresh or dry corn fodder, is no more remarkable than that koumiss should be so much better as an article of diet, in many cases, than the best fresh milk. Koumiss is nothing more than fermented milk, and many physicians of large experience are constantly using it, and have seen numerous cases where it would be impossible to give milk under any other article of diet, when koumiss is readily taken and retained. It would seem as if through the process of fermentation it had been carried on one stage in the process of digestion, and that 
thus far it could be more readily appropriated or assimilated in the stomach. When farmers come to regard the preparing of ensilage as a chemical process, which with proper manipulation and care may always be relied upon to give uniform results, and will consider the food thus preserved as a valuable adjunct to their winter supply of feeding stuff rather than material fit to supplant all others, the true value of a silo will be appreciated and acknowledged, and a silo will be regarded essential on very well ordered farms.

\section{H. M. HOWE.}

E. W. Ross \& Co.,

\section{Chaklęston, S. C., February 8, 1881.}

Gentlemen:-In reply to your circular, I will state generally that my silo was formed by excavating into the side of a welldrained clay hill, a pit of the capacity of full 150 tons, sides supported by rock, walls of the thickness of 15 inches.

The ensilage from corn, Indian, cut in roasting ear $\frac{1}{4}$ inch in length, well trodden by two heavy men, always in motion during: the cutting. The excavation was greatly facilitated by the use of a scoop and yoke of oxen in the removal of the earth from the pit, and may have been used in packing, in the place of two men, had it not been objected to for its want of cleanliness. After filling, 18 inches of clean straw was placed all over the ensilage and then well fitted boards, heavily weighted with stones, and over all a good roof, extending 18 inches from the wall, so as to protect the silo from rain and moisture. Cost including Ross Cutter, about $\$ 600.00$.

Along with my corn I placed one layer of green clover cut and used in with oat straw. My manager, Mr. Wood, writes me that his beeves from the first feed greatly relished the corn ensilage, 
feeding each 50 lbs. per day, but was comparatively indifferent when fed on the mixture of clover and oat straw. Mr. Wood, a practical and well-educated Scotch farmer. is greatly pleased with this, his first experience with ensilage, but does not recommend it as a feed alone; his system is to give a full ration of hay and corn with this addition; his beeves thrive-satisfactorily; so much so that in future be will reduce materially his turnip crop, upon which he formerly depended in a great measure, preferring the ensilage, not only as food, but far less expensive in the cultivation of corn over turnips.

More accurate information may be obtained by addressing $\mathrm{Mr}$. Wood, Calhoun, Transylvania Co., N. C.

Should this crude statement prove worthy of publication, I prefer that my name should not be used, but you may substitute that of my farm.

VALLEY HOME, North Carolina.

E. W. Ross \& Co.,

Salisbury Center, Herk. Co., N. Y.

Dear Sirs:-Agreeable to your request, I herewith send you some items of my experience with the silo and ensilage system. I will not give detailed account of construction, only say we used a small bay in one end of barn. Excavated twelve feet below sill and planked up ten feet above. Have used it two seasons, first with corn exclusively.

This season, 1883, put in thirty-five tons, "so estimated," of green clover, when nicely in blossom, put on pressure at the rate of 1,000 to $1,100 \mathrm{lbs}$. to the square yard. When time to put in corn, removed weights, and filled up with about same quantity of corn and weighted as before.

When opened, found it bright and nice, and weli preserved. Stock are very fond of it. When ready to fill silo, having no 


\section{7}

ensilage cutter, and as it would be less expense, and we could perform the labor more within ourselves, were disposed to put it in whole. But I don't claim this method to be the better way. If cut fine when siloed, no doubt it will pack closer, and I think it may. contain less acidity when opened for feeding. Enables stock to masticate and dispose of it with more ease, and better relish; therefore would much prefer the cutting process. Our plan of feeding is one ration of ensilage per day in the morning, average from 20 to $25 \mathrm{lbs}$. to each cow. At evening, about what dry fodder they will dispose of. Find that stock does better than to confine them to either exclusively.

In feeding corn or clover ensilage, stock seem to have but little preference, and very little variation in quantity of milk changing from one to the other. We have no accurate account of the expense of building silo; my estimate, which I think is nearly correct, is $\$ 150.00$. In filling silo we find it less expensive to put corn into ensilage, than the old method of binding, and stouting up. I think the time will soon come when the silo and ensilage system will be more practically and better understood, and will be pursued with as little complexity and difficulty as most any other farm labor, and be of immense value to the farming community. No doubt the benefit of feeding ensilage to stock is not so fully appreciated as its merits deserve. Years before this discovery, or practice of feeding, we were troubled every year more or less with cows not doing well. when coming in, but, with our present practice of feeding, I think there has not been an instance that they have not disposed of after-birth within two or three hours' time. It seems to be congenial to the nature of stock, keeps them strong and thrifty, and so far as my experience goes, am fully satisfied with its results.

My estimate favoring the feed of ensilage may be in part owing to the farm we cultivate, which makes the advantages more practicable. Some parts of it are light and sandy, not adapted to grass. If seed is sown, it is nearly thrown away, growing not more than 
half a ton per acre. But by plowing shallow with good tillage, and sowing corn with grain drill, nearly two bushels per acre, and about $250 \mathrm{lbs}$. of fertilizer with corn in drill, this method gave satisfactory results.

We use southern white corn for seed. Those having poor farms and keep dairy of cows, I think would find it greatly to their interests to adopt, the ensilage system.

Respectfully yours,

DAVID TUTTLE.

\section{SILOS AND ENSILAGE.}

\section{By V. D. Taylor, South Richford, Vt.}

\section{PRELIMINARY REMARKS.}

In attempting to say a few words upon the above subject, I am well aware that the ground that I am about to tread upon is considered by a large majority of people at the present timeas debatable, and also that there are people who are so bitterly opposed to the ensilage system, that they persistently shut their eyes to all facts in the case, totally ignoring everything that has been proven by experiment during the last two years, claiming that the theory is a humbug, and that money invested in building silos is worse than thrown away.

Now all I have got to say to the latter class of people is, come over and examine my silo and ensilage, and see for yourselves whether or not I have exaggerated anything in any of my statements; and to the former, that I stand ready to debate with them at any time and place they may see fit to appoint.

The practical solution of the saying: "Be not the first nor the last to try an experiment," has proven of inestimable value, times without number, to those who have had the nerve and pluck to go 
ahead without waiting for somebody else to demonstrate beyond a doubt that the theoretical solution of an untried proposition is correct.

Solomon tells us somewhere in his writings that there is nothing new under the sun, and as far as preserving ensilage by storing it in pits in the ground is concerned, we are told that the art is as old as the hills; and who knows but what Noah may have had a silo in his ark. If I remember aright, science has not given us any light upon the antiquity of this point, although we are told from this source that there is nothing in ensilage but water. I have great respect for science, and I am also glad that there is such a thing as theoretical knowledge, for were it not for the latter we should not be led to try experiments; but as to the former, I do not believe that it will prove profitable to any man in the long run to be led blindfolded by scientific sophisms contrary to reason. An all-wise Providence has implanted within the head of every thinking individual a desire to investigate, but the spirit of old fogyism is yet rampant in the land, and views with equal distrust the attempts of science to establish a truth and the vindicators of theoretical knowledge to prove by practical experiment a hypothetical supposition. Smith says, there is a propensity to push theory too far; but what is the just inference? Not that theoretical propositions of any considerable comprehension or extent should, from such their extent, be considered to be false in toto, but oniy that in the particular case inquiry should be made whether, supposing the proposition to be in the character of a rule generally true, an exception ought to be taken out of it. It might almost be imagined, to hear some people talk, even in this, the 19th century, that there was something unwise in the exercise of thought. I am not given to speculation. I am no friend to theories. Can a man disclaim theory, can he disclaim speculation, without disclaiming thought? Again, to quote the above-mentioned author, "when reason is in opposition to a man's interest," he ought to have said his future inclination, "his study will naturally be to render the faculty itself, 
and whatever issues from it, an object of hatred and contempt." The sarcasm and other figures of speech employed on the occasion are not directed merely against reason, but against thought, as if there was something in the faculty of thought that rendered the exercise of it incompatible with useful and successful practice.

Now, would not it be well for men who feel an uncontrollable desire to brand every new idea as speculative, to take a look into the merits of the particular case which they are branding as theoretical, visionary, chimerical, and all humbug, before they give us the benefit of their sarcasm, as they have upon the ensilage question?-and when they have demonstrated by practical experiment that the theory is a humbug, then we will take their say, so far, for what it is worth; but in the meantime we who know the theory is correct will do what we can to bring the system to perfection by building more silos, thus proving our faith by our works. Now, brother farmers, I am not going into a long dissertation upon the ensilage question, but I shall just give you my practical experience in as brief a manner as possible, and you who have a desire to increase your stock and enrich your farms at the same time, just read the following experience carefully, or give me a call; and I will show you how you ean double your stock the first year, and in less than three years how to keep twenty-five cows on six acres.

\section{THE WOODEN SILO.}

My silo is built entirely of wood, directly under my upper barn floor. When I built my barn, I built with the intention of having two silos under the floor, if I liked the first experiment. My first experiment is a success, and accordingly I shall finish off another silo the coming season. A wooden silo can be built of one hundred tons capacity, that wiil not cost over fifty dollars, if a person has timber so that he can get out his own lumber. The cheapest way to build is to build with matched lumber, single board, and stuff with sawdust. I built mine by putting $2 \times 4$ ribs on to an eight-inch wall, boarded the outside up and down upon the girts, 
and the inside upon the ribs horizontally, thus making a strong wall, and giving me ten-inch space to stuff with sawdust; the size of silo is $13 \times 18$ on the ground, and fifteen feet high up to the upper floor. I can put in ensilage thirty feet deep by taking out a section of the barn floor, when I am filling the silo, thus making it hold twice what its natural capacity would be were it not finished above the floor; the bottom of silo is nearly on a level with my stable floor, a door opens directly into the feeding floor of the sta. ble from one corner. I make this door tight by putting in matched boards on the inside and stuffing from above with sawdust.

One of the most important features in builaing a silo is to have it so constructed that you can feed out the ensilage without being put to too much trouble, and you can just as. well have it handy as otherwise, if you will just use a little common sense in planning the silo from the start. You must bear in mind, when building, that you have got to feed out the ensilage, as well as to put it in, and that the filling-time occupies but a short period, while the feeding-time lasts all winter.

\section{FILLING THE SILO.}

I was six days in filling my silo. Commenced to fill it September 16th. The corn was badly frosted, consequently I did not expect any very good results from my ensilage this year, but $I$ have been very agreeably disappointed. I put in about twenty tons of white western corn sowed especially for the purpose, and three acres of oats, and on top of that my field-corn fodder, after picking off the ears, and top of that about a foot of rowen. I cut the whole of it, with the exception of the rowen and about a foot of corn fodder, into half-inch lengths, with a one-horse power and a Ross Fodder Cutter. That which I did not cut I put in for the purpose of trying an experiment, and it has convinced me that the right way to put in ensilage is to cut it up, as the cattle cannot eat the large stalks unless they are cut up fine After getting all my fodder into the silo, I covered it with matched boards, and weighted with 
stone, putting on about one hundred pounds to the square foot. (It is very important to have the boards cut just the right length, for if they crowd on the wall and do not settle clear, the ensilage will not pack hard enough to keep out the air.) I believe that it does not make any difference how long you are in filling a silo, if you only keep at it until you get it filled. At least, the length of time that I occupied in filling mine would seem to indicate that the above inference is correct, as mine came out in good condition, and continued so, with the exception of the oats, until the last of it was fed out.

\section{MY EXPERIENCE IN FEEDING ENSILAGE.}

I commenced to feed ensilage the 11 th day of November, and fed it clear for seven days to twenty-four head of cattle. Before I had completed the fourth day my cows had gained up double in their milk. At the end of the eighth day, I commenced to mix my ensilage with cut hay, mixing it about half and half, and feed. ing three bushels a day up to the first day of February; then I commenced to mix a bushel of shorts a day with the feed, mixing up the three feeds together, and letting it stand over night. My cows never looked better than they do at the present time. They commenced to gain in flesh as well as milk almost immediately after commencing the new "departure," and have continued to gain up to the present writing.

If any one is skeptical or doubts what I am stating, I can refer them to scores of visitors that have visited me during the past winter for the purpose of seeing the "rotten stuff," and among all that have interviewed me, I have yet to learn of a single individual who has gone away without coming to the conclusion that there is something in the "Ensilage System " besides "Humbug." I have not fed fifty pounds of good hay since I commenced to feed ensilage. The hay I have been cutting is poor, late-cut stuff, consisting chiefly of wild grass, brakes, and weeds. I have enough ensilage left to feed a month longer, which will make, in the whole, 
fully five months of feed in connection with the hay mentioned above. Now, in view of these facts, taking into consideration the amount of ensilage that I had in the start, "estimated to be forty tons." the length of time that I have been feeding, the number of head of cattle fed, and their condition as they appear at the present time, I am led to believe that the corn fodder undergoes a process of fermentation while in the silo that adds greatly to its nutritive value. I am not a chemist, consequently I cannot give the relative constituents of the ensilage that I have been feeding; that it is rich in nitrogenous, free extract substances, such as starch, sugar, etc., I cannot doubt; at least, I am willing to take the testimony of the old red cow upon this point without putting it to a chemical solution. At any rate, I am not going to denounce it as "nasty, stinking, unhealthy stuff," as long as old Red continues to prefer it to the best of hay or even meal.

\section{"CUTTING AND SHREDDING."}

There has been a machine invented for shredding ensilage, which consists of small circular saws set close together on a horizontal shaft. The shredding operation consists in running the corn fodder over the saws lengthwise. Now, as far as getting the ensilage out of the silo is concerned, it would be just as hard work to get it out if it were shredded as it would the whole corn fodder, and then it would be just as bad stuff to mix with any other feed, as uncut hay, and I would not take a silo full of uncut corn fodder if I could have it given to me free of cost, unless I was in the same position of the stuttering old farmer, who, when asked if it paid to manure corn in the hill, replied, "yes, if you have got a lot of boys that you don't have to hire." Still, notwithstanding the fact that it is hard work to get it out of the silo, some are putting in the fodder whoie, and seem to like the process well. This is no argument against cutting, but an argument in favor of the silo, for if it pays to put it in whole, it is much more profitable to cut it, for this reason: when ordinary corn 
fodder is fed without cutting, the animals reject the hard lower parts, and of this a large percentage finds its way to the manure pile, making the manure very difficult to manage or handle, while if it is cut up fine it is very easy to handle or to mix with anything, and cattle will eat it all up clean.

E. W. Ross \& Co.,

Rochester, March 10, 1884.

Gentlemen:- - Your kind letter came duly to hand, in which you requested me to give my experience on silos and ensilage. I will gladly do so, as I do not think anything has been discovered within the last ten years that will benefit the farmer so much as the process of keeping green fodder for his stock through the winter.

Two years ago I built a silo of stone, the walls being twenty inches thick, laid up in water lime. As my farm is on the Genesee flats, and is liable at certain seasons of the year to be overflowed, I was obliged to build above ground, with the exception of four feet.

The dimensions are: 30 feet long, 16 feet wide, 20 feet deep. I used in its construction 50 bbls. water lime. It is plastered on the outside five feet high, on the inside to the top, with a grout bottom five inches thick. It will hold from 180 to 200 tons; were four days filling it. As soon as full we put on the cover and weights, amounting to $300 \mathrm{lbs}$. pressure to the square foot. Did not open it until six weeks later, when I found it perfectly cool and in splendid condition. I sowed Burrell \& Whitman's southern sweet corn, believing it to be the best that grows for ensilage. I have raised twenty tons to the acre for the past two years, and expect this year to get thirty.

I am milking thirty-five cows, and find that ensilage will pro- 
duce more milk than anything I can feed, as my contract will not allow me to feed brewers' grains.

Last winter I fed thirty nine head of stock five, months and twenty days. with the ensilage I put up in September, giving each cow two bushels per day with a feed of dry corn stalks at noon. The cost, including seed corn, plowing, planting, cultivating, cutting, drawing, and filling silo, was $\$ 1.18$ per ton. This does not include the cost of silo, which was $\$ 350.00$. It is a pleasure to see the cows eating green corn in the month of December, when the ground is covered with snow, and not a green thing to be seen around the farm excepting what the silo contains.

I am satisfied that the time is not far distant when you will see every farmer with a silo. I would not take three times the cost of mine, if I could not have another. While I am speaking of ensilage, I want to say a word about the Ross Ensilage Cutter. I tried two cutters before buying the Little Giant, manufactured by E. W. Ross \& Co. I believe it is the best machine made for cutting ensilage. The only fault I find with it is that we cannot get the corn to it fast enough.

Hoping soon to have the pleasure of reading the experience of your many customers and friends, I remain,

Respectfully yours,

E. A. LODER.

E. W. Ross \& Co.,

Gaylordsville, Conn., March 17, 1884.

Sirs :-In answer to your inquiry on ensilage, I would say I find it a pretty good feed. I do not consider it as valuable as some, neither do I consider it as worthless as some others. I find it does well when fed once or twice a day, with some hay and grain between times. I do not think I get the flow of milk that 
s me pretend to get. My silo is built mostly under ground; cannot give the exact expense, as barn and silo were built at the same time. I have no faith in cheap silos built above ground, as they will soon wear out, and be very inconvenient to fill and weight.

Ensilage should be put into the silo dry, as it will not mould when exposed to the air at feeding-time, which it will if put in when wet.

Litchfield County.

Yours truly,

JOHN FLYNN.

Harnerstown, Monmoush Co., N. J., February 28, 1884. Messre. E. W. Ross \& Co.,

Dear Sirs:-In reply to your inquiry, asking my experience of ensilage, etc., I would state, that my silo cost about $\$ 350.00$, is of brick, five feet below and ten feet above ground, with a wooden building on top five feet high with a shingle roof, with two tie beams across directly over and forming a part of the partition in th silo; inside measurement, 30 feet long, 12 feet wide, 20 feet deep.

The walls are $9^{\prime \prime}$ thick, with four places on each side $14^{\prime \prime}$ thick by $18^{\prime \prime}$, to give more strength. The bricks are laid in cement mortar. Bottom and sides cemented. Doors in end next to stable one foot above top of ground.

For two years I filled it all in one silo, taking five days to fill it. I then divided it into six compartments so that I could fill and close a section each day, and I like it much better than having one large silo. The silo is divided by a partition lengthwise and two cross-ones made of two-inch plank. tongued and grooved, except six feet of cross partitions, above level of bottom of outside doors, where the planks are put in so that they may be removed in 
taking out the ensilage; that space is covered with building felt before filling. In feeding it out I remove the entire cover from the section.

I covered the doors with building felt to make them air-tight. I covered the ensilage with two layers of inch boards, broke jointed, and weighted with stones, about 1,500 lbs. to square yard. The silo stands 14 feet from the stable. I use a two horse railway power standing in second story of stable.

The corn is brought to the cutter on wagons, and is cut about $\frac{3}{8}$ inch long, and taken in at top of silo by means of large barrows, holding some eight bushels, and dumped. I keep it well trodden while filling. My way of raising the corn is to prepare the ground as for wheat, and about the 10th of June $I$ sow it, using a grain drill, shutting off all but two tubes, planting the rows about four feet apart and a bout eight grains to the foot.

The cultivation consists of running the cultivator or horse-hoe through it twice.

The cost of growing, putting in silo, and weighting it, has been for three years about $\$ 1.22$ per ton, not including rent of land. I found the ensilage good in contact with the wood partitions, and some three inches of waste next to the brick; that leads me to believe that wood will keep it better than bricks-any cheap wooden structure will keep it better than the very costly ones, but they must be air-tight, which can be easily done by lining the inside with roofing felt.

I had great doubts about the practicability of the system, for it seemed to me to be so unreasonable to keep corn in a green state, and to add to my doubts, such great things were claimed for it; so I thought I would go slow in the matter. In the fall of $1879, \mathrm{I}$ dug a pit, five feet deep, eight feet wide, and filteen feet long, and filled it with Stowel's Evergreen corn, cut in $\frac{3}{8}$ inch lengths. The pit was lined with, and ensilage covered with, 3 inches of straw covered with 2 feet of earth. When I opened it the following 
March, the sides and bottom were somewhat spoiled, but the greater part was a splendid feed.

The cows ate it readily, and increased at least ten per cent. in their milk, and the quality was so much better that, on delivery to the creamery, the foreman remarked that it looked like grass milk, and asked what I was feeding. I have since shipped milk to one of Philadelphia's largest milk-dealers, and he requested some of his other customers to find out what I fed my cows on, and for them to feed the same.

I have nearly doubled the cows I kept before using ensilage. I feed it to all my cattle, from six months old. I feed full-grown cows forty pounds per day, and from two to eight pounds of grain, and once a day a bundle of corn fodder; on wet days a little hay. After my experience, I fully believe in the system, and that cheap wooden silos will keep it, that more than double the number of cows can be kept, and that it is the cheapest and best food we can get. The best ensilage I have had, has been of sweet corn. cut when you could pull some for boiling. and the poorest when less than half of the stalks showed silks for ears. It is most important when filling to keep it of equal compactness.

NICHOLAS WALN.

E. W. Ross \& Co.,

Gorham, Maine, February 4, 1884.

Gentlemen:-I was considering the ensilage question some time before I moved in that direction, thinking that I was obliged to put two or three hundred dollars into building a silo, but I found out that it is not necessary.

Last summer, I prepared me a silo for an experiment. I took a part of my ice-house, put a partition up with seven-inch plank edgewise, boarded each side with hemlock boards, and filled space 
with sawdust. My silo is $15 \times 20$ and fourteen feet high, all out of the ground. Then I ordered a No. 14 Ross Cutter, which is not second to any, and I can cheerfully recommend it to all my brother farmers as being all that is claimed for it. I planted twenty acres of sweet corn for canning: sold the corn, and siloed the fodder.

I commenced filling my silo the 5th of September, under very unfavorable circumstances. The severe drouth damaged the fod. der very much, and the early frost made it about worthless; so I concluded that my experiment would be a failure, but as I could silo it cheaper than I could dry it in the field, I concluded to persevere, and I did so.

I filled my silo, covered it with two-inch plank, and weighted it with five tons of stone. It settled about three feet. The 25th of November, I opened it, and to my surprise, it was in better condition than I expected to find it. I took about three inches from the top, that was somewhat moldy, and the remainder was all right; so I concluded that a cheap silo would keep ensilage.

I have fed forty head of cattle since November '25th, and thirty of them are cows, and they all eat it with a relish, and have increased in the flow of milk, and have laid on more flesh than ever before in winter. As poor as the fodder was, my cows will leave the best hay and take the ensilage, and I have not a bundred pounds of waste from my twenty acres of corn fodder.

I feel so well pleased with my results, that I am preparing another silo that will hold a hundred tons more; but I shall use the old one as long as it will last. So, brother farmers, you can have a silo as well as your neighbor, with a small expense. I cannot tell you the expense of raising it per ton. It will depend on the condition of the land; but the expense of putting it into the silo, for me, was about fifty cents per ton.

Yours truly,

H. B. JOHNSON. 


\section{SILOS AND ENSILAGE.}

WALpole, N. H, January 21, 1884.

The giving my ideas of silos and ensilage, and the result of the benefit derived from same, will be of little benefit, as there are many who have given the subject more thought, and have been so situated that the result can be given much better.

I have two silos, one built in 188\%, of wood above ground. It is in the north end of what used to be a cider-mill. I cemented the bottom with a coat of cement about two inches thick; the sides are double-boarded, with paper between. Dimensions, $21 \times 10 \times 12$ feet. The cost of this was twenty-five dollars for the lumber and cement. I did the work at odd jobs; perhaps my work was worth five dollars-making the cost thirty dollars. This silo was partially filled with corn fodder raised for the purpose, but the season was very dry, and my crop was light; but the ensilage was all one could wish, for it kept perfectly, and my stock never did better than when fed on the contents of this cheap silo. I was so well pleased that I concluded that I must build another, so, in the following spring of 1883 , I took a bay in one of my harns (the barn has a cellar under it) for the purpose of a larger silo.

I dug down seven feet into the ground and used stone and cement for the wall. After getting up a little above the ground, I used studding and double-boarded, using paper between, as on the silo No. 1. This silo is now $21 \times 10 \times 28$ feet, and a chance to extend the boarding up as high as the high beams of the barn.

I planted white Southern corn for ensilage on the 25th day of June, and the $3 \mathrm{~d}$ day of September commenced filling my silo, cutting it with a Ross Cutter. The cost of putting the ensilage in silo was one dollar per ton. The cost of planting and cultivating was not very expensive, as I used a harrow soon after the corn came up and then cultivated twice. What the exact cost was, I cannot tell, as I kept no particular account of my time. I raised 100 tons on the $3 \frac{1}{4}$ acres of ground, using nothing but stable manure. 


\section{1}

After filling my silo, I put in a layer of straw and planked it over, then took some boards and laid round the edges of the planks and put on stone enough to just make the plank level and no more. Then put on six or eight inches of sawdust and called it completed. On the 15th day of October, I opened it, and found it all right, even the straw on top looked as bright as when put on. Since that time I have been feeding ensilage to cows, oxen, sheep, hogs, and poultry, and consider it the very best way of keeping stock. as the cows give more milk, and of a better quality, than when fed on hay. Oxen gain flesh and enjoy their feed; sheep are greedy for it, and it seems to be just what they want or need. Just how much this silo cost I cannot tell, as iny hired man and myself did all the work.

I used 30 bbls. cement, and about $2 \frac{1}{2} \mathrm{M} \mathrm{ft}$. of lumber, worth $\$ 14$ per M. It took a good many days to do the work, but I feel as if it was time and money well spent. The ensilage kept as well in the first" or cheap silo, as in the other, which most persons would call the best one. I am so well pleased with the result of feeding ensilage the preserit winter, that I shall try and raise enough to fill both another year; and the most I have to say to my brother farmers is, if you want to keep double the stock you now keep and keep it better, then build a silo, and you will, I trust, never to be sorry for the money and expense you have been to in doing it.

\section{O. J. HUBBARD.}

$1_{\text {Altic, Conv., March 18, } 1884 .}$

Dear Sirs :- I understand that you are about to issne a book treating on the value and the effect of ensilage. Having had some experience in feeding the same for the last two years, I would beg leave to ask you to look over this document and give it a place in your book, if not received too late. 
In 1881 I bought a farm in the town of Franklin, that some years ago did rank among the best farms of New London county. But, like other good old farms, the buildings, and particularly the land, was entirely run out, so much so that the parties could not winter any more than seven head with all they could secure on the place.

I had read the book of $H$. $R$. Stevens on ensilage, and the different methods of building silos. With what notions I had learned from the book and people talking, I built a silo big enough to hold two huudred tons, at a great deal more expense than there was any need of, and I went to using corn for ensilage. I used what manure I could scrape from the farm, and spread on to $2 \frac{1}{2}$ acres of land the most handy to the barn, and succeeded very well.

I ensilaged about sixty tons, and had no more hay than my predecessors, but I wintered sixteen head horn cattle and four horses, and in the spring, when the cattle went to pasture, I had five tons of hay and about as much ensilage left.

From that time I came to the conclusion that in order to bring old farms to the good state of, cultivation we must have manure, and the -best way to have it is to make it by increasing your number of head of stock, and raise corn fodder for ensilage to feed.

Last year I sowed double the land that I had the year before, but did not succeed, for the first reason that of the corn I sowed more than half the seed did not come up, and then frost in the fall cut it very badly, so that I could not increase my stock any; but I have enough to winter the same number of head. Next fall I expect to be able to winter thirty head. I believe that silos will redeem the New England farms, provided that every farmer builds one and fills it properly. It is not much of a job to build a silo; you can build of wood or stone, cheap. As to the filling of silos, there are various opinions about the time one should take in filling. and in regard to that, I think the quicker they are filled and weighted the better.

The first year I cut my ensilage with a two-horse tread-power 
and No. 42 Cycle Cutter, and it gave me very good satisfaction. We did the work well, and in a hurry; but last year I bought a No. 14 Ross cutting machine, and with the same power I did the work to a better satisfation, and kept all my men on the run to keep it a running. It is the most reliable, easily fed, and no grinding to the knives, as we had to do with the Cycle machine. I worked the machine three days, and did not grind the knives, and did the work nicely. As to the experiment of feeding ensilage to see its effect in milk, etc., etc., I am not able to say anything about it, as I have not made any as yet. Yours,

P. S. COTE.

Messers. E. W. Ross \& Co.,

Preston P. O., Conn., March 2, 1884.

Gentlemen:-In building my silo I excavated ten feet deep, and built the stone-work three feet above, and banked up with dirt, making thirteen feet of stoning, on top of which I put a wood frame $12 \times 20$ feet, with eight-foot posts.

Part of the stone-work was laid dry and grouted with cement mortar, and part was laid dry and pointed, and plastered.with the same. On the inside, above the stone, I put on one covering of matched chestnut boards, and over that one covering of matched pine and spruce; estimated cost of excavation, $\$ 50.00$; estimated cost of whole concern, $\$ 300.00$. . Last of May, and first of June, planted Southern white corn three feet apart, in rows eighteen to twenty-four inches between the hills, with one handful of Coe's phosphate to three hills, with manure spread on a small part; corn, manure, and phosphate the year previous on the same land.

September 3, 1883, began to fill silo, and in five days put in four acres, filling silo eighteen feet and six inches after the covering was on. I covered it with two-inch oak plank, with a six-inch 


\section{4}

board under under each seam. Settled just one-fourth of the depth. Cut with a two-horse-power and a Ross Cutter No. "14A," which runs beautifully, and I don't think it can be beat by anything of its size. I cut my ensilage one-quarter inch, but am now inclined to think that one-half is better. The fine cutting on the large fifteen-inch pulley that came with the cutter made slower cut. ting than it otherwise would have been. In filling I had one man in silo to spread it even, and one to tread, and some of the time, more. I don't think heavy treading is so essential as it is to see that all parts are kept equally full and hard, as I think if there is any soft spots they will be liable to be moldy. I commenced feeding one bushel a day to twenty-four head of cows and heifers the 7th of November, and I think it will last them until about May. They seem to like it, and will eat it in preference to the best of hay, although it is quite sour, and has a decidedly vinegary taste. The first cutting that I took out had several inches of juice in the bottom, and a disagreeable smell. I think I. cut my corn too young. I now believe it should be planted thin enough to form some ears, and they should be ripe enough to eat. I have planted fodder-corn twenty-five years or more, more or less, and have found by experience that if fed before it is spindled, it would diminish the quantity of milk and injure the quality of butter. If we can put poor feed into the silo and have it come out good, it must be very remarkable. I think the silo should be adjoining: the stables, and nearly on a level with them. I don't like hoisting up when it is so much easier to throw down; for a wood silo, I would board up inside with two coverings of rough boards, or one thickness of two inch-plank, and then lath it and plaster with cement mortar. When I first began to read about this ensilage business, I thought it was all studied out and perfected, but I now think there is much to be learned yet. I went through my corn once with cultivator and hoe. What I did not feed green, or put. in silo, I cut and set up in large shocks, and let stand until I fed it.

ANDREW AVERY. 
Messrs. E. W. Ross \& Co.,

New YoRk, April 2, 1884.

Gentlemen:-In reply to yours of February 4 th, in reference to ensilage, I can say very little, except as it comes to me from my farmer.

My business proper is in this city, and I only make occasional trips to the farm. I had experience on the farm in boyhood, and therefore take to this business more naturally than if without any experience. I never made any calculation as to the cost of raising or cutting. As to the former, most depends upon the richness of the soil, and to get it in and store it the cost will greatly depend upon the way it is managed. Give me land rich enough to raise a good crop of corn, and I am not afraid to get in and store it at a very low cost.

We have used your cutter, and a two-horse tread power, and had no difficulty to cut a ton in twenty minutes, and store it in silo at the same time, by means of your elevator, which carried it nineteen feet at an elevation of eleven feet. Our custom has been to have two men in the field cutting, two teams and one man at the cutting machine, while the two men and teamster are loading, while the other teamster is unloading his load, on the platform of the cutter, as fast as the man at the cutting machine can feed it.

My silo was built in the end of the barn, $10 \times 12$, and 25 feet deep, boarded up. It is made of matched boards, and when filled we weighted it with stones from 75 to $100 \mathrm{lbs}$. to the square foot. This I find sufficient for us, as we can cut our corn $\frac{1}{4}$ to $\frac{1}{2}$ inch in length.

The weighting with stone I find takes but a short time, as well as the removing of them. Much has been said against the practice of using stone, and the vast amount of labor attending it, etc. This I presume comes from those that have no experience of farm work, or from that "lazy" class who are afraid of work, and never will make ensilage, or anything requiring labor, a success. I have not tested ensilage sufficiently long to give that opinion you call for. 
Two years ago my silos were not built in time to store a great deal; and last year, in consequence of late planting; and a very cold season, I was obliged to cut it before it came into tassel, lest the frost would catch it. In this condition it had not fully

- matured, and I do not think it contains the strength it would have had if stalks were in tassels.

Ensilage made from corn cut in this condition keeps well, looks nice, and is free of dust. My farmer writes me, "I like to feed it to the cattle. They are fond of it, and eat it ravenously. After feeding it over a month with hay, and same amount of feed, fall to see that they have become more thrifty or are doing any better than before we fed it. The labor of feeding it is no objection to silo; neither do I discover the much-talked-of taste in milk and butter; nor do I think it affects either in that respect. Some of the cattle can be fed on it in unlimited quantities, with impunity, while with others an overdose goes through them like a dose of salts. The pigs eat it sprinkled with feed voraciously, but I think the feed does more for them than the ensilage."

My present farmer has only been on my place this winter, and has had no knowledge as to the growth of the corn, and that it was not fully matured when cut, for he adds, "corn does not mature in this latitude nor do corn-stalk grow to perfection." A silo filled with twelve-foot corn stalks having large ears of corn on, grown in Monmouth county, New Jersey, on marl bottom land, might be fed with very different results.

Sweet potatoes, grown in Virginia and Delaware, are very superior to those grown in the vicinity of New York; both the flavor and keeping qualities are better. Corn grows more to perfection in Virginia than in my own county, Monmouth. Climate and soil have a great effect on amount of nutriment contained in plants of different kinds.

Yours truly,

J. L. OBERLY. 


\section{THE ROSS ENSILAGE AND FODDER CUTTERS.}

To those who decide that they will adopt this system, and who wish to cut their ensilage, we would respectfully call their attention to our line of cutters. We make a specialty of this class of work and have a very superior line of machines. We would like to have them examine our circular, and if they believe that our machines are the best, and at reasonable prices, hope they will give us a trial. We ask no one to buy our machines unless they are fully up to our representations. We are perfectly willing that they shall be tried beside any other make in the market, for the reason that we know there are a great many cutting machines, as well as other classes of goods, that are inferior and not what they are - claimed to be, and farmers are often imposed upon by manufacturers of inferior articles. We believe and guarantee our machines to be the best in the world, and guarantee every cutter we sell to give satisfaction or no sale. We do this as a protection to farmers in general, and to our customers. We are selling cutters constantly throughout the United States, and frequently receive orders from foreign countries, and extreme Western States, enclosing money with their order, which shows the confidence they have in our machines. We take particular pains to always see that these people are supplied with machines that are in every way first.class, and that they receive full value for their money. We have done business here a great many years, and expect to continue. We cannot therefore afford to deceive any of our customers. We do not ask anybody to keep a machine that we sell them, if they find any other cutter in the market for the same price that will do the same 
work without breakage, etc. Our prices may be higher than a great many inferior machines in the market, but it is not an uncommon thing for us to sell one of our cutters to a customer when he has been offered cutters from other manufacturers at from $\$ 10$ to $\$ 25$ less money. We have never yet had a machine sent back to us that we have sent out on our guarantee. Of course we do not expect to sell all the machines that are sold, but it is our endeavor to get our legitimate share of the trade. Our prices are no higher than we are obliged to make them, and give first-class, guaranteed work. We can build cutters as cheaply as any manufacturer in the world, and we do not expect any larger profits. Consequently we believe that our cutters are the cheapest to buy, for they will stand heavy work without breakage, and are always ready. We hope that our friends who contemplate buying a cutter will send for our circular and write for prices before buying.

Yours truly,

Fultow, N. Y., April 2, 1884.

E. W. ROSS \& CO. 


\section{IMPORTANT.}

Please remember that our Machines will do double and treble the amount of work, size for size, that can be done by any other make in the country, and that they are heavier, stronger, and more durable. Also, that our smaller sizes do equal the amount of work that is done by the largest size and more expensive Cutters of other makes; consequently you can buy of us a Cutter which requires less power to drive it, will do better work, will not get out of order, and is guaranteed to give satisfaction, for considerably LESS MONEY than you can secure a Machine for of other makes with an EQUAL capacity, while for large sizes our Machines cannot be approached by several TONS per hour. 


\section{NOTICE.}

It frequently happens that our customers find some of the parts of the machine broken or missing when they come to use the machine, and at once write us for the duplicate parts, claiming that the parts were broken or lost by the railroad company. We in many instances have sent the extras, and charged them to the railroad company receiving the goods from us. After a long investigation, railroad companies have reported the goods delivered and receipted for in good order. Under these circumstances we could not force our claims, and must therefore stand the loss, when in reality the railroad companies are at fault. We always send a duplicate shipping receipt with each shipment, enumerating all of the pieces and bundles, and it is our express desire that our customers check the goods in by these receipts, and if there are any parts broken or missing, to make claim before accepting or receipting for the goods. We can then assist them in recovering from the railroad company, but otherwise we cannot. Our responsibility ceases when goods are delivered on cars here and properly receipted for, unless otherwise agreed upon.

In ordering, state size of pulley wanted, and which side the cutter will be driven from, left or right, standing at the feeding end, and give full shipping directions.

For carriers, give height of wall from feet of cutter, and thickness of wall. Full directions will be sent with each cutter. 


\section{GENERAL PRICE LIST.}

\section{The Ross Hand Cutters.}

No. $5-2$ knives, . . . . . . . $\$ 2.00$

" $9 \mathrm{~A}-3$ knives, . . . . . . . 30.00

" $12 \mathrm{~A}-3$ knives, two men to turn, . . . $\quad 38.00$

\section{The Ross Little Giant Power Cutters.}

No. 11 A-4 knives, . . . . . . . $\$ 45.00$

" $13 \mathrm{~A}-4$ knives, . . . . . . . . 65.00

" $14 \mathrm{~A}-4$ knives, . . . . . . . 90.00

" $17 \mathrm{~A}-4$ knives. . . . . . . . 140.00

\section{The Ross Giant Power Cutters.}

No. 18A-4 knives, chain feed, . . . . $\$ 250.00$ " $26 \mathrm{~A}-4$ knives, " " $\quad$. . . . 300.00 All power Cutters have the Ross Patent Safety Fly-Wheel. 


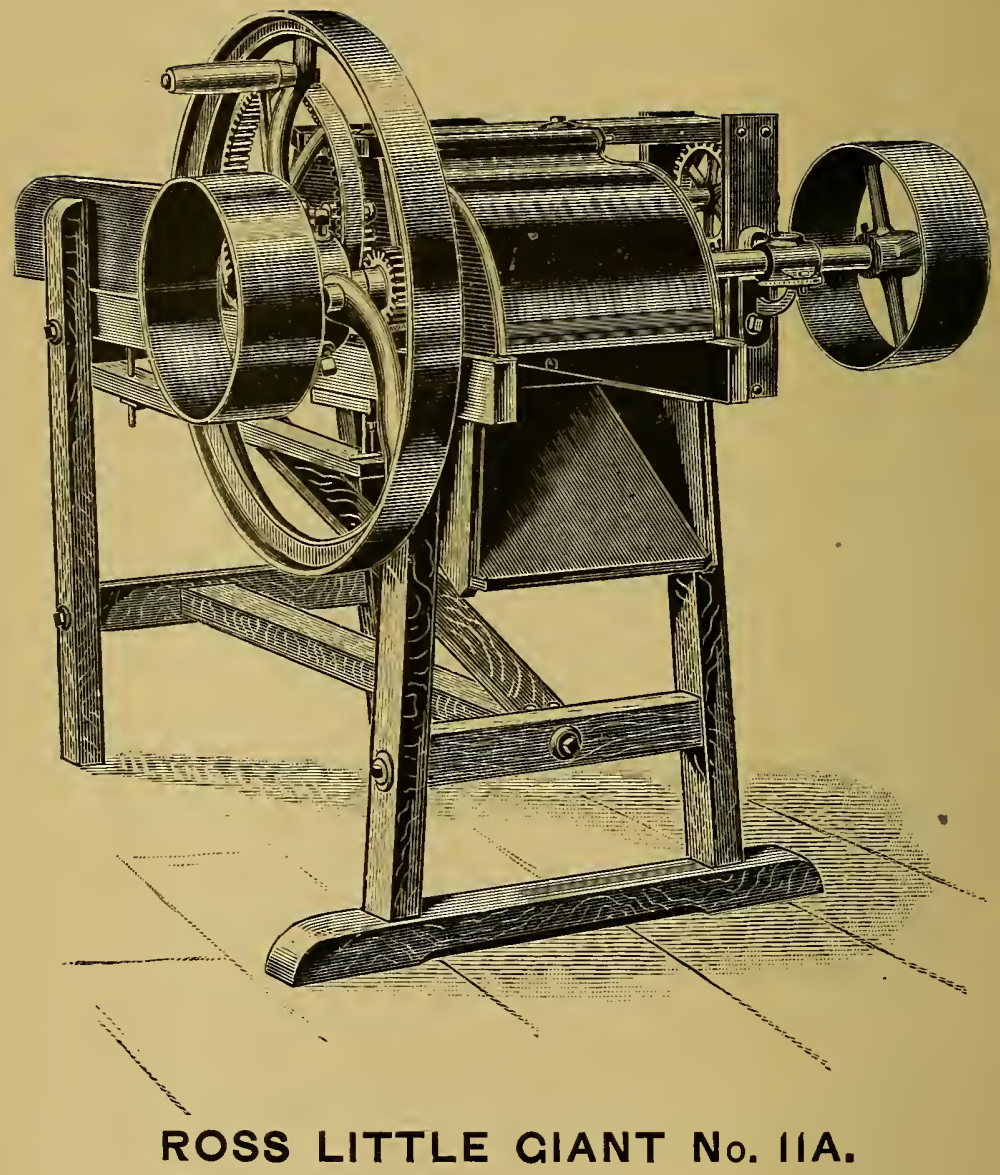




\section{The Ross Little Giant Cutter No, $11 \mathrm{~A}$.}

The No. 11A is our smallest power-cutter, and is especially adapted for cutting all kinds of dry fodder. It has four 11-inch knives with long shearing and upward cut. It can be driven upon either side, as ordered, by 8,10 or 12 -inch pulley. It has the Ross patent safety fly-wheel, extensible joints, convex gears, self adjusting feed-rollers, swing hood, and all of the new improvements. It is one of the finest power-cutters in the market, and we guarantee it to give perfect satisfaction. It can also be run by hand power. Cuts one-fourth, one-half, and one inch.

CAPACITY, 2,500 pounds per hour.

Power required, one horse.

SPEED, 500 to 600 revolutions per minute.

WeIGHT, 350 pounds.

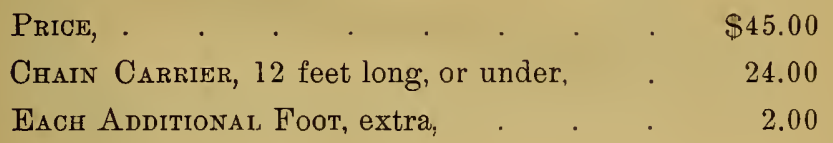

The No. $11 \mathrm{~A}$ was not designed for an Ensilage Cutter, and we do not recommend it for that purpose, although some of our customers have used this size with good success. Our Nos. 14 A, 17 A, $18 \mathrm{~A}$, and $26 \mathrm{~A}$ are especially adapted for cutting ensilage, and we can guarantee them in every way. 


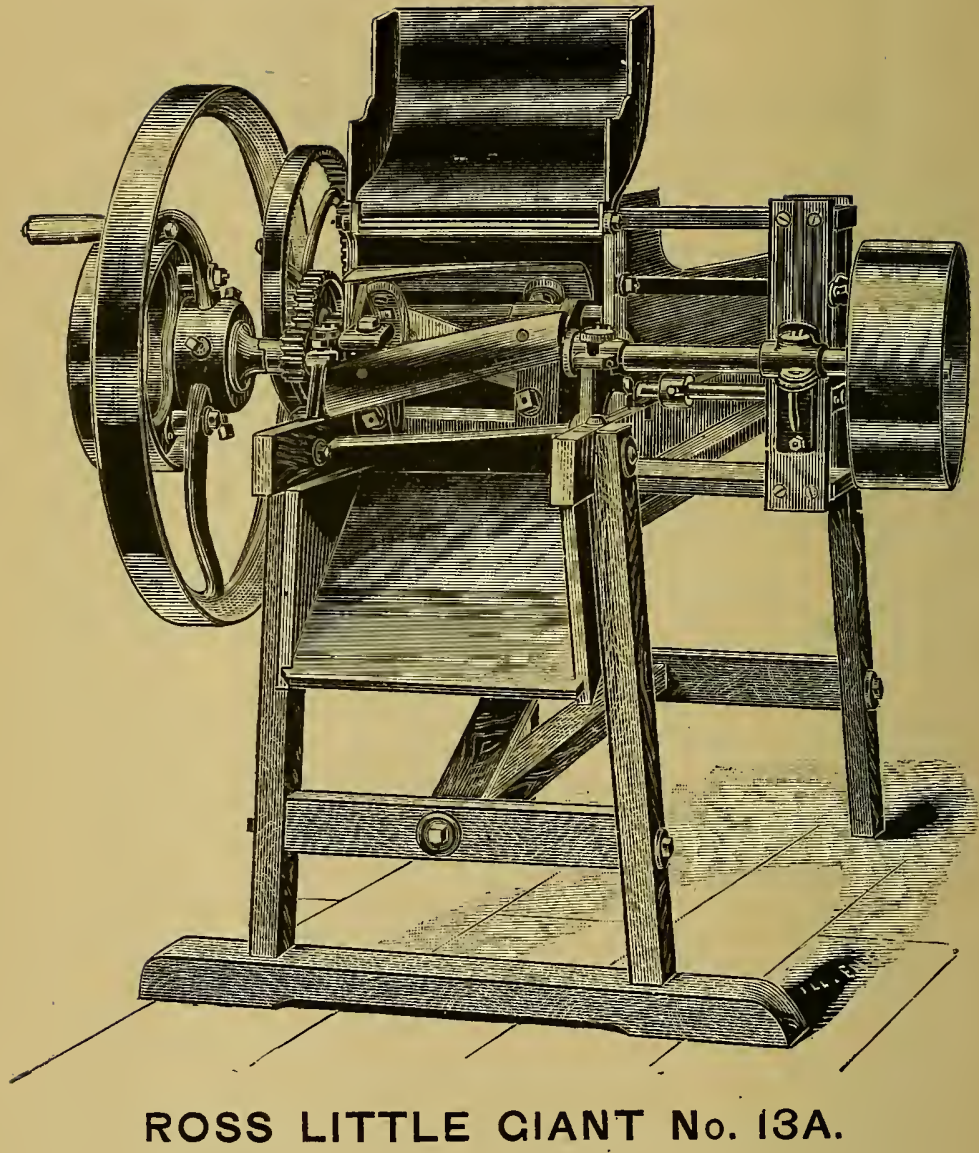




\section{The Ross Little Giant Cutter No. 13A.}

The No. $13 \mathrm{~A}$ is the next size larger than the No. $11 \mathrm{~A}$, and of the same pattern. It has four 13 -inch knives with upward shearing cut. It is fifty pounds heavier than the No. $11 \mathrm{~A}$, and stronger in proportion. This is the most convenient size we have for the general farmer. It is an easy-running cutter; can be run by hand or one-horse-power, and has a large capacity. It is intended for cutting all kinds of dry fodder, and has no equal for the price. We guarantee this cutter in every way.

Cuts one-fourth, one-half, and one inch.

CAPACITY, 3,000 to 3,500 pounds per hour on dry fodder.

Power required, one horse.

SPEed, 500 to 600 revolutions per minute.

WEIGHT, 400 pounds.

Pulleys, either $8,10,12,14$, or 16-inch diameter, as ordered.

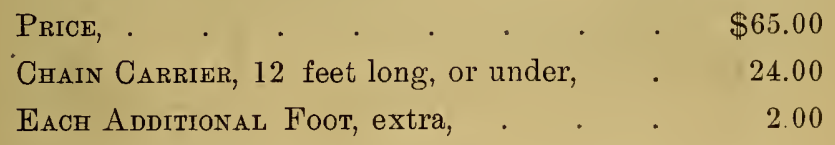

The No. 13A is not one of our Ensilage Cutters, and we do not recommend it for that purpose. It is, however, a very superior machine, and will do excellent work. Our 14A, 17A, 18A, and $26 \mathrm{~A}$ are made especially heavy and strong, and are perfectly adapted for cutting ensilage. 


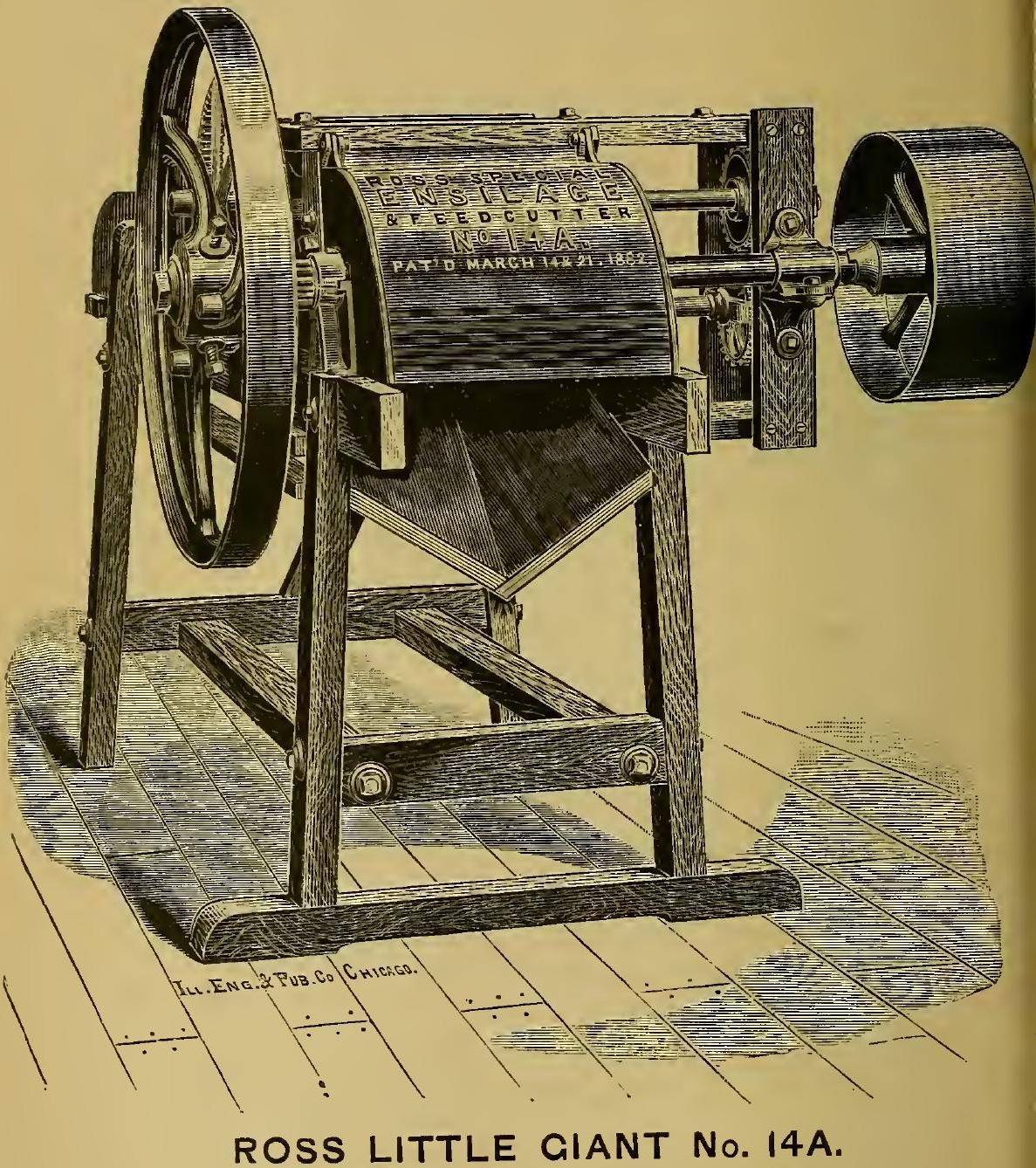




\section{The Special Little Giant Cutter, No. 14A.}

This is one of our "Specials," and designed to be the very best machine it is possible to build. Is extra heavy, strong, and durable, and is intended for heavy work. It cuts equally well, and in a perfect manner, every kind of green and dry fodder, including the largest of corn-stalks. It requires but very little power to drive it. Provision is made for attaching an extension to the end of feeding box for facilitating rapid and easy feeding of machine.

The driving pulley and fly-wheels can be changed to either side. Cutter has an extra provision for long springs to increase the universal motion of the feeding rollers, and is provided with every improvement and device for making it superior in every particular. We cannot recommend it too highly.

MaCHINe HAS-Four 14 -inch knives, and weighs 575 pounds.

" " - Two pulleys for belting on either side.

" " "-Pulleys either $8,10,12,14$, or 16 -in. diam. as ordered.

" " - Extra heavy and long shafts, with three bearings.

" " " - Safety fly-wheel and pulleys, changeable.

" " " - Heavy flaring frame of selected timber.

Cuts $\frac{1}{4}, \frac{1}{2}, \frac{6}{10}$, and 1 inch long.

" " "-Provision for receiving Carrier at any time.

" " "Capacity on green fodder of five tons per hour.

Cutter should run from 500 to 600 revolutions per minute. Power required, including Carrier, 2-horse tread or sweep.

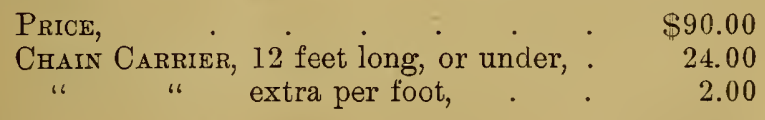

The 14A is one of our Regular Ensilage Cutters, and is the best. cutter of its size in the world. 


\section{The Special Little Giant Cutter, No. 17A.}

Is one of our "Specials," and designed to be the very best cutter it is possible to build. It is precisely similar in construction to the.No. $14 \mathrm{~A}$, only heavier and larger and of greater capacity. It will cut more fodder, green or dry, than any cutter of any other make (excepting our Giants) in the United States. The capacity is not controlled by the length of knives, and it does its work with ease and freedom, and in a most perfect manner. The machine requires but very little power to drive it, and is furnished with two pulleys for belting up on either side at will, and arranged for attaching Carrier at any time.

MACHINE HAS-Four 17 -inch knives, and weighs 775 pounds.

" " "Two pulleys for belting on either side.

" " " $\quad$-Pulleys either $8,10,12,14$, or 16 in. diam. as ordered.

" " "Shafts with three bearings, extra heavy and long.

" " "-Safety fly.wheels and pulleys, changeable.

" " "-Heavy flaring frame of selected timber.

" " -Cuts $\frac{3}{16}, \frac{7}{16}, \frac{5}{8}$, and 1 inch long.

" " -Capacity on green fodder, eight tons per hour. Cutter should run from 500 to 600 revolutions per minute. Power required, 2-horse tread or sweep.

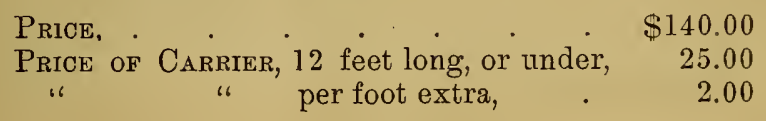

The $17 \mathrm{~A}$ is one of our Ensilage Cutbers; and is a very superior machine in every respect. 


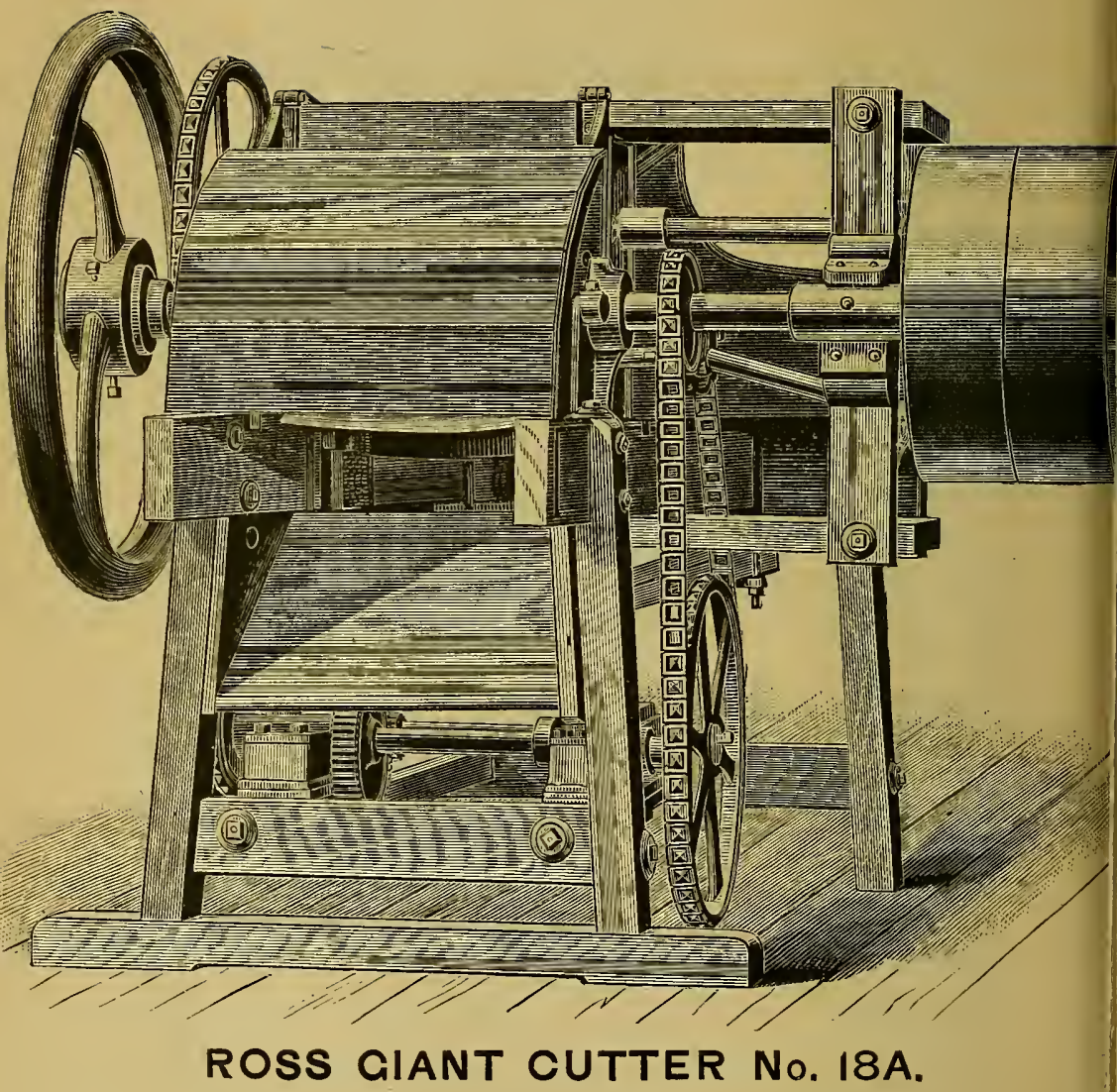




\section{The Ross Giant Cutter No. 18A.}

The No. 18A Giant is next in size to our largest Ensilage Cutter, and is a very large and powerful machine. It has an almost unlimited capacity, and cannot be excelled, except by our $26 \mathrm{~A}$. Except in size, it is the same as the 26A. Our Giants have all the new improvements, and are guaranteed to be as represented.

IT is very heavy and strong.

HAS four 18-inch knives and upward cut.

Pulleys, either 20, 24, 26, or 30-inch diam., 6-in. face, as ordered. Shafts extra heavy and long, three bearings.

SAFETY fly-wheels.

Driven upon either side, as ordered,-generally left side.

Frames very heavy and flaring, and from selected timber.

CuTs $\frac{1}{4}, \frac{3}{8}, \frac{1}{2}, \frac{5}{8}, \frac{3}{4}$, and 1 inch long and upwards.

WEIGHT, 2,000 pounds.

CAPACITY, ten tons per hour, one-half inch long.

SPEED, 600 revolutions per minute.

Power, five to six horse-power engine.

Detachable chain feed.

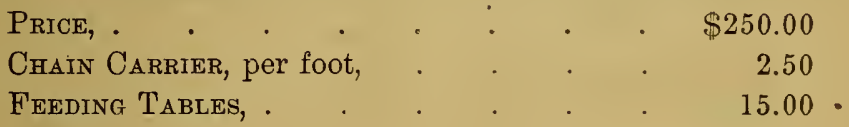

We can furnish this cutter with downward cut, if desired, upon sufficient notice. 


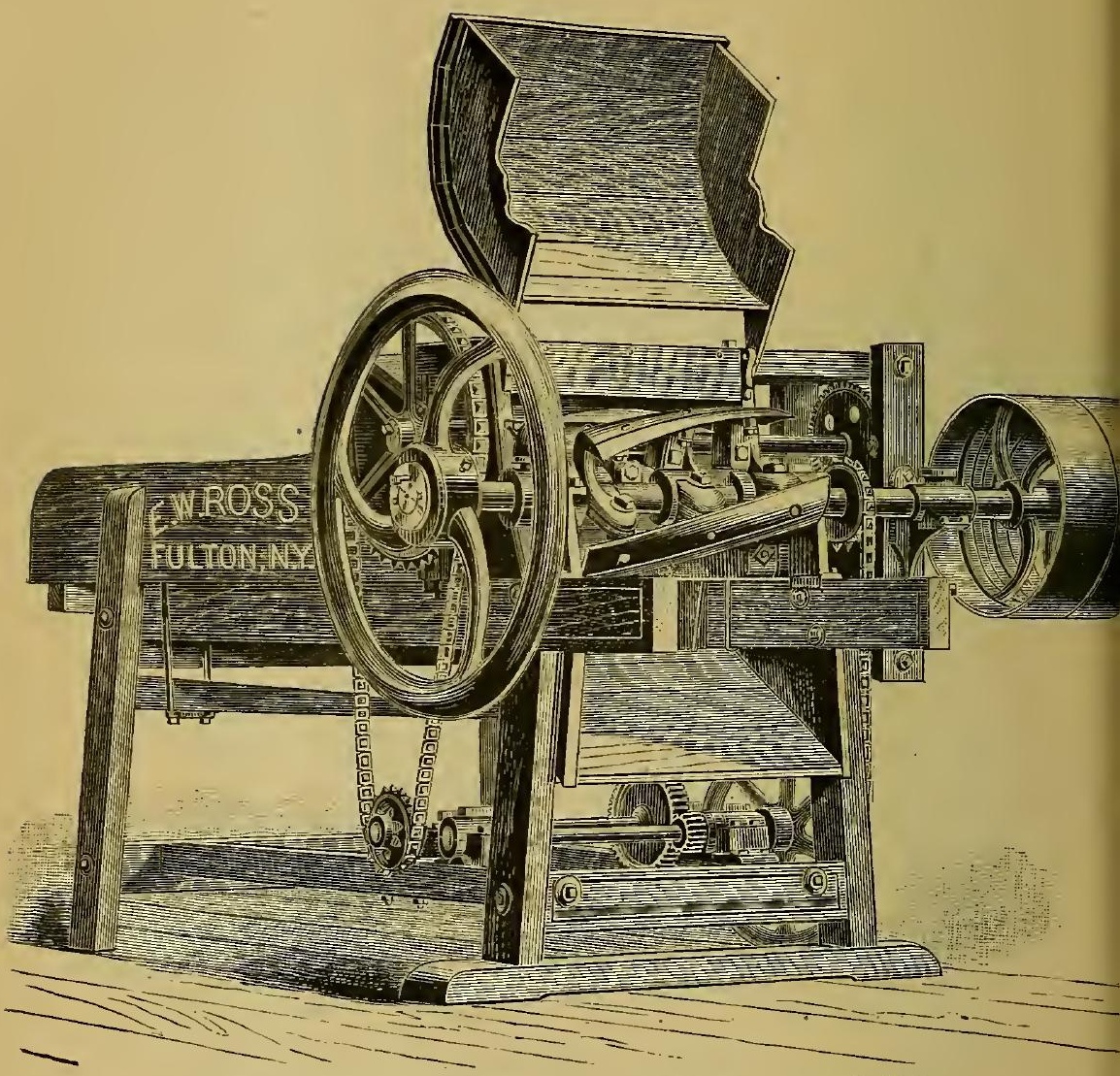

ROSS GIANT CUTTER No. 26A. 


\section{The Ross Giant Cutter No. 26A.}

The No. $26 \mathrm{~A}$ is the largest and most powerful Ensilage Cutter in the world. It has an unlimited capacity, and we guarantee it to be superior in every respect to any other cutter in the world.

IT IS very heavy and strong.

$\mathrm{H}_{\text {AS }}$ four 26 -inch knives, and upward cut.

Pulleys, either 20, 24, 26, or 30-in. diam., 6-in. face, as ordered. ShaFts very heavy and long, three wide bearings.

SAFETY fly•wheels.

Driven upon either side, as ordered,-generally left side.

FrAMES very heavy and flaring, and from selected timber.

Cuts $\frac{1}{4}, \frac{3}{8}, \frac{1}{2}, \frac{5}{5}, \frac{3}{4}, 1$ inch and upwards.

WEIGHT, 2,500 pounds.

$\mathrm{C}_{\mathrm{APACITY}}$, fifteen tons per hour, one-half inch long.

SPEED, 600 revolutions per minute.

Power, seven to eight-horse-power engine.

Detachable chain-feed.

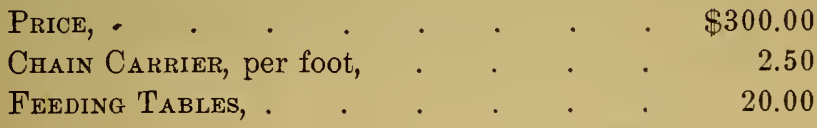

We can furnish this cutter with downward cut, if desired, upon sufficient notice. 


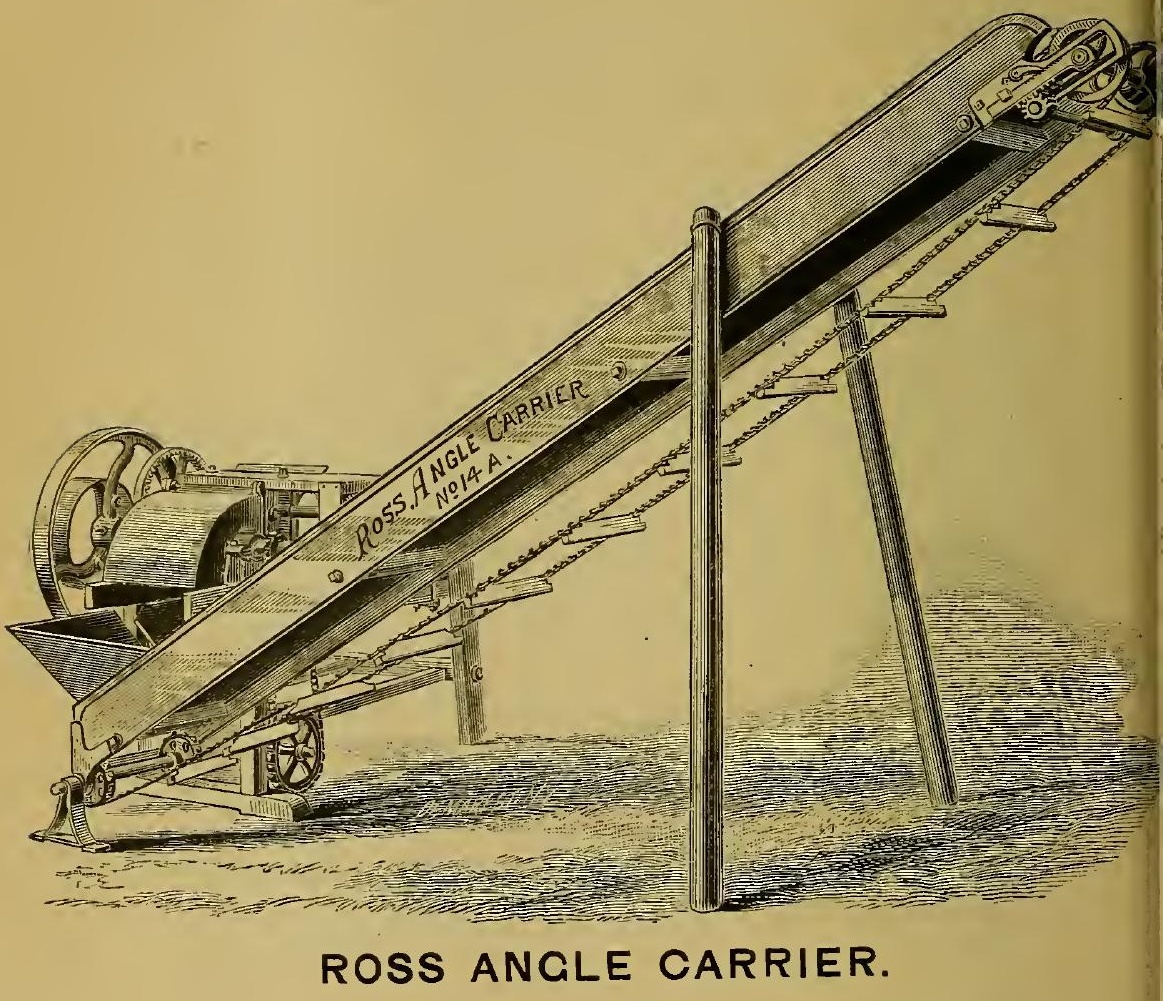




\section{CARRIERS.}

\section{Ross Patent Angle Carriers.}

This Carrier is our very latest design (1883), and destined to supersede all others. It is reversible. On page 94 the carrier is shown delivering to the left, and can also be changed to deliver to the right, and with the devices provided, this change is very easily and quickly made. Also please notice that the driving belt of the cutter runs directly away from the machine, and not backwards on either side. This arrangement, unlike the straight delivery carrier, enables the user to place the cutter close up to the silo or bin, into which the fodder is to be carried or elevated; or in narrow drives or passageways. It also leaves the feeding end of the machine clear all around it for wagons, material, and workmen, and permits its being fed on either or both sides, as best suited for receiving the material to be cut, which advantages are too apparent to need explanation.

Heretofore it has been necessary to belt back beside the cutter, when straight-away carriers were used, thereby shutting off completely with the driving belt all of one side of the machine, and preventing its approach with wagons, men, or material, doubling the cost of preparing the fodder, and proving a great annoyance and expense. 
This carrier requires but the very least power to drive it - the friction of the working parts being reduced to a minimum, and it works so easily that in turning a large cutter by hand, the difference is hardly perceptible, whether the carrier is attached to the machine or detached.

All the working parts are fully exposed to view, and can be readily oiled. This is the only carrier where the whole of itself and load is supported by an especial device which relieves entirely the shafts and boxes from that weight, and at the same time holding firmly and securely in position the bottom shafts and chain-wheels, thus preventing their slipping or moving while being attached, elevated, or detached. The chain we put upon these carriers is made of malleable iron, and can be quickly detached, or put together at any point.

Cut on page 94 shows at upper end of carrier our patent device for taking up the slack of the chain and buckets after they are hooked together when setting up the carrier, and afterwards for regulating at ali times the proper tension of the chain. The action on both sides is simultaneous, and accomplished in a moment. This device entirely prevents the difficulties heretofore experienced with all carriers. The chain will not slip, jump the teeth, stretch unevenly, or break, but will run smooth and free under the hardest work. The wood work is thoroughly framed, and put together with joint bolts, and the sides are very high, suited to our cutters, which require carriers of good capacity to remove the cut stock.

Carriers are fast coming into favor, and are furnished with nearly every large cutter, and will be found not only to save the labor of from one to five men, but will do the same amount of work quicker, cleaner, and at no expense after first outlay. They deliver off upon the same level or will elevate to an angle of fortyfive degrees, every kind of material, green or dry, and being entirely of iron and wood, do not soak up or fray out. Are used also either by hand or power for carrying ensilage or dry fodder from the storing-places to such points as it may be necessary to. 


\section{7}

feed. "They are indestructible, require the least possible power to drive them, will deliver either to the right or left, are positive drivers, and do not clog, slip, or stop; are easily and quickly attached or detached ; require no belt to drive them; are heavy, strong, and durable; can be made in sections to any length; have our patent adjusting and tightening device; have no equal for perfection of operation, durability, or capacity, etc., etc."

Covered by patents, and can be had only of ourselves or our agents. 


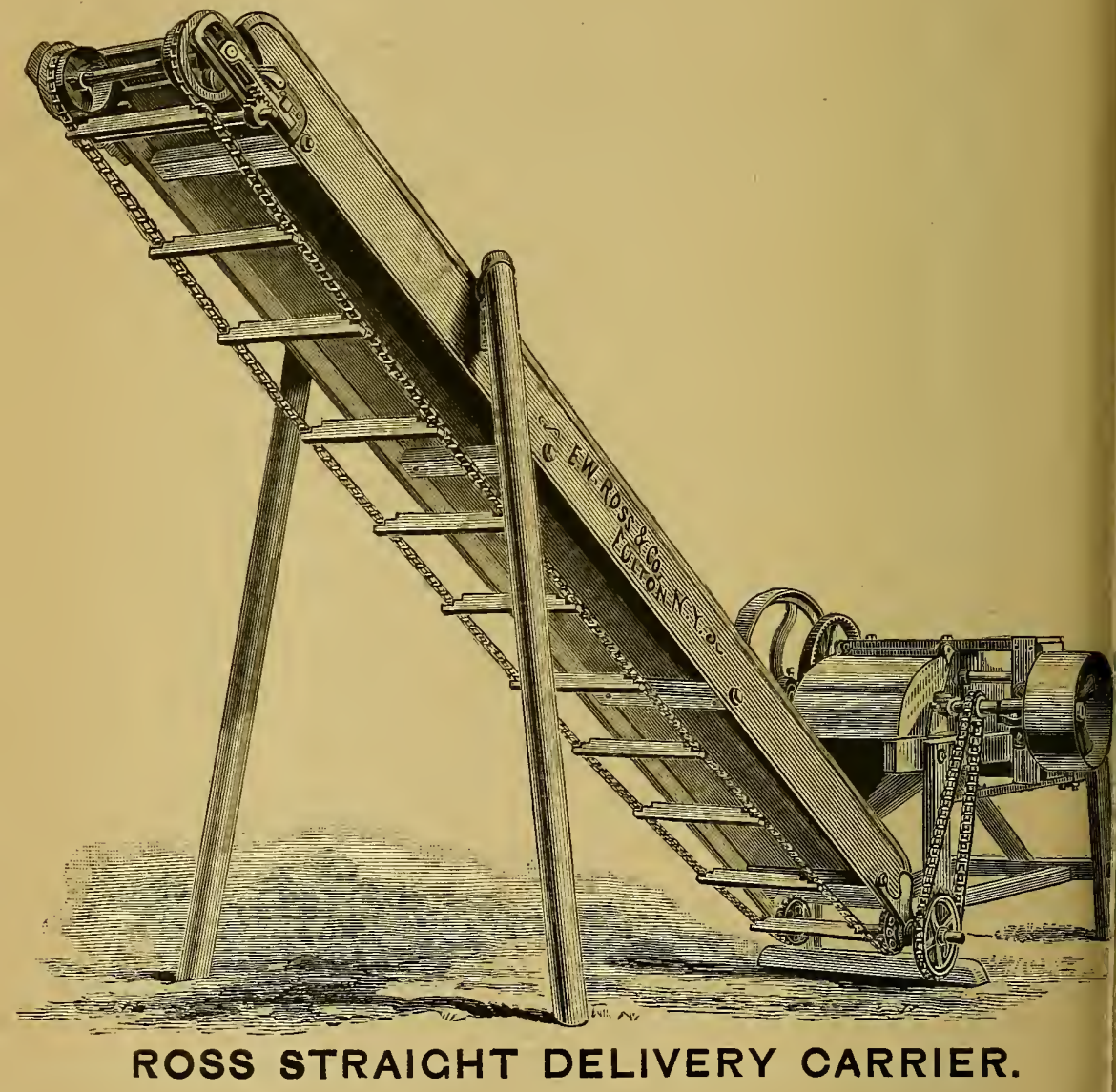




\section{Straight Delivery Carriers.}

These are our latest design (1883), and in general construction and operation are similar to our angle carriers, and covered by the same patents, excepting that they do not deliver sideways. When arrangements are provided or circumstances of the case admit of driving the cutter either from below, above, or straight-away, without belting backward past the feeding end of cutter (thereby shutting off one side of machine completely, like every and all others, excepting our patent angle), then they will be found to be very satisfactory, and will do just as good work as the angle style. The carriers are provided on all short lengths with means for driving as shown on pages 94 and 98 .

Material and workmanship is the same as in the angle style, and in every particular of construction and operation the same, excepting this delivers straight-away and the angle style at right angles, either right or left side as desired. 




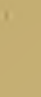

$\sqrt{2}+x^{2}$

(

, 


